Michał Michalski

(Wieluńskie Towarzystwo Naukowe)

dr, michalmichalski1982@wp.pl

ORDCID iD: 0000-0002-5267-8150

\title{
Emigracja sezonowa do Niemiec z powiatu wieluńskiego w okresie międzywojennym (1918-1939)
}

\section{Wstęp}

Do połowy XIX w. w Polsce, a po rozbiorach także z ziem polskich, przeważała emigracja polityczna, a zjawisko emigracji zarobkowej miało charakter marginalny. Do lat 40. XIX stulecia znacznie częściej obserwowano imigrację na ziemie polskie niż wyjazdy w poszukiwaniu środków do życia. Pierwsze agitacje emigracyjne o charakterze zarobkowym zostały odnotowane w Królestwie Polskim w latach 20. XIX w., a mianowicie w 1824 r., gdy wśród chłopów i „pospólstwa” w województwie płockim rozeszła się pogłoska o poszukiwaniu chętnych na wyjazd do Portugalii. Z kolei w 1845 r. pojawili się pierwsi emigranci skuszeni wizją pracy w Stanach Zjednoczonych Ameryki, którzy po przekroczeniu granicy mieli otrzymać pomoc od władz pruskich, finansowaną przez prezydenta USA. Jednakże ostatecznie czekała na potencjalnych pracowników deportacja do Królestwa Polskiego ${ }^{1}$.

Przeprowadzona w $1864 \mathrm{r}$. reforma uwłaszczeniowa nie rozwiązała kwestii agrarnej, a kryzys z lat 80 . XIX w. pogłębił trudności samodzielnych gospodarstw, skąd rekrutowała się większość emigrantów, toteż: „Nie mogły utrzymać się bez dodatkowych zarobków karłowate gospodarstwa. Podstawowego kontyngentu wychodźców dostarczyło jednak młode pokolenie, często wywodzące się z rodzin chłopów-gospodarzy, ale nie dziedziczące ziemi. Nadwyżki siły roboczej, zwłaszcza w mniej uprzemysłowionych re-

${ }^{1}$ J. Kozłowski, Emigracja okresu schyłkowego Rzeczypospolitej szlacheckiej i porozbiorowa (do 1864 r.), [w:] Emigracja z ziem polskich w czasach nowożytnych i najnowszych (XVIII-XX w.), pod red. A. Pilcha, Warszawa 1984, s. 23-119. 
jonach, nie mogło wchłonąć miasto. Również spośród tych, którzy się w nim znaleźli, rekrutowali się potencjalni kandydaci do emigracji w obliczu trudności na rynku pracy. Takim rezerwuarem niewykorzystanej siły roboczej stały się również liczne miasteczka, często pozbawione praw miejskich, o rolniczym charakterze" ${ }^{\prime 2}$. Na to nałożyła się jeszcze eksplozja demograficzna, która rozpoczęła się $\mathrm{w}$ latach 50 . XIX w. na zachodnich ziemiach polskich i od lat 70. XIX w. w Królestwie Polskim i w Galicji ${ }^{3}$.

Także mieszkańcy powiatu wieluńskiego wyruszali na poszukiwanie pracy za zachodnią granicą - pierwsze sporadyczne wyjazdy były w wieku XVIII, a chętni udawali się na Śląsk Opolski lub do Wrocławia ${ }^{4}$. Jednak największe natężenie emigracyjne przypadło na lata po 1890 r., wówczas bowiem zezwolono na zatrudnianie sezonowe pracowników bez rodzin, głównie $\mathrm{w}$ rolnictwie ${ }^{5}$.

Tabela 1. Emigracja sezonowa z powiatu wieluńskiego do II Rzeszy na tle Królestwa Polskiego w latach 1890-1912

\begin{tabular}{|c|c|c|c|}
\hline \multirow{2}{*}{ Rok } & \multicolumn{2}{|c|}{ Powiat wieluński } & \multirow{2}{*}{ Królestwo Polskie } \\
\cline { 2 - 3 } & Robotnicy & $\begin{array}{c}\text { \% emigracji z Królestwa } \\
\text { Polskiego }\end{array}$ & 17275 \\
\hline 1890 & 6590 & 38,15 & 119184 \\
1900 & 18951 & 15,90 & 137701 \\
1904 & 24,4 tys. & $\approx 17,72$ & 235074 \\
1908 & 34,6 tys. & $\approx 14,72$ & 322350 \\
1912 & 39,5 tys. & $\approx 12,25$ & \\
\hline
\end{tabular}

Źródło: Obliczenia własne na podstawie: K. Groniowski, Emigracja z ziem zaboru rosyjskiego (18641918), [w:] Emigracja z ziem..., s. 213-217.

\section{Charakterystyka społeczno-gospodarcza powiatu wieluńskiego}

Zakończenie I wojny światowej przyniosło odzyskanie niepodległości przez Polskę. W powiecie wieluńskim, który zbytnio nie ucierpiał na skutek zniszczeń wojennych, oszacowane straty bezpośrednie wyniosły bowiem tylko

\footnotetext{
2 K. Groniowski, Emigracja z ziem zaboru rosyjskiego (1864-1918), [w:] tamże, s. 196. Został zachowany oryginalny zapis we wszystkich cytatach.

${ }^{3}$ J. Kozłowski, dz. cyt., s. 99.

${ }^{4}$ J. Milczarek, Emigracja zarobkowa z wieluńskiego (1918-1939), „Łódzkie Studia Etnograficzne" 1977, t. 19, s. 7.

${ }^{5}$ K. Groniowski, dz. cyt., s. 213-217.
} 
41890 rubli, przy ogólnej wartości budynków 14344370 rubli. (0,29 proc.), sytuacja była jednak trudna ${ }^{6}$. Pod względem materialnym bardziej dotknęły mieszkańców wszelakie rekwizycje dokonywane przez okupantów, którzy rekwirowali bydło, trzodę chlewną, konie, drób, ziarna zbóż i innych roślin, sprzęty domowe, papierosy, broń itd. ${ }^{7}$, a także „Dla zabezpieczenia na wypadek odwrotu frontu w 1915 r. Niemcy zryli pola siecią okopów wyłączając z produkcji duży obszar ziemi, który trzeba było po wyzwoleniu zniwelować, co kosztowało masę pracy. [...] Wiele rodzin odczuwało brak gospodarzy, zabranych przez Rosjan do wojska, w innych gospodarstwach brak było rąk do pracy, bo Niemcy polskich robotników zatrzymali do końca wojny"8.

Powiat wieluński, przedzielony w czasie Wielkiej Wojny linią demarkacyjną biegnącą rzeką Wartą pomięd zy Generał-Gubernatorstwo Warszawskie i Generał-Gubernatorstwo Lubelskie, w większości trafił pod okupację niemiecką, a pod austriacką znalazły się gminy: Działoszyn, Kiełczygłów i Siemkowice oraz część gmin: Konopnica, Mierzyce i Radoszewice9. Po odzyskaniu niepodległości Komisarz Rządu Polskiego na Powiat Wieluński Ignacy Bąkowski na podstawie decyzji z 1 grudnia 1918 r. w skład powiatu wieluńskiego włączył gminy: Działoszyn, Kiełczygłów oraz Siemkowice, a 1 stycznia 1919 r. część gminy Radoszewice wraz z częścią gminy Konopnica ${ }^{10}$.

${ }^{6}$ Z. Limanowski, Zniszczenia wojenne w budowlach b. Królestwa Polskiego, Warszawa 1918, s. 33; M. Przeniosło, M. Przeniosło, Rada Główna Opiekuńcza w latach 1918-1921, Kielce 2018, s. 17.

${ }^{7}$ Archiwum Państwowe w Łodzi Oddział w Sieradzu (dalej: APŁOS), Starostwo Powiatowe Wieluńskie (dalej: SPW), sygn. 235, k. 1-106 Listy strat wojennych; J. Lewandowski, Okupacja austriacka w Królestwie Polskim (1914-1918), „Dzieje Najnowsze” 1998, r. 30, nr 4, s. 29, 32-37; T. Olejnik, Praszka w latach I wojny światowej, [w:] Nad górna Prosna. Monografia Praszki, pod red. T. Krzemińskiego, Łódź 1999, s. 322; J. Książek, Życie społeczno-polityczne i gospodarcze Lututowa w latach 1914-1939, [w:] Sześć wieków Lututowa. Studia i materiaty, pod red. T. Olejnika, Wieluń 2007, s. 112; tegoż, Pierwsza wojna światowa (1914-1918), [w:] Monografia gminy Wierzchlas, pod red. Z. Włodarczyka, Wierzchlas 2014, s. 257-261.

${ }^{8}$ Muzeum Ziemi Wieluńskiej (dalej: MZW), Zbiory Specjalne (dalej: ZS), nr 114/sp.in, k. 5. W. Zarzycki, Kółko rolnicze w Białej k. Wielunia - dawniej i dziś. Ogólne straty wojenne ziem polskich nie są znane, a ich wielkość jest różnie oceniana. Zob.: E. Kołodziej, Gospodarka wojenna w Królestwie Polskim w latach 1914-1918, Warszawa 2018.

${ }^{9}$ J. Pajewski, Odbudowa państwa polskiego 1914-1918, Warszawa 1985, s. 93; T. Olejnik, Przeszłość administracyjna Ziemi Wieluńskiej, Wielun 1996, s. 25-27; A. Chwalba, Historia Polski 1795-1918, Kraków 2000, s. 576.

10 Ogłoszenie, Dziennik Urzędowy Komisarza Rządu Polskiego na Powiat Wieluński (dalej: DUKRPPW) 24.01.1919, nr 2, s. 21; T. Olejnik, Przeszłość administracyjna..., s. 29. Komisarz nie wydał (lub nie opublikowano) zarządzenia dotyczącego włączenia części gminy Mierzyce oraz zniesienia gminy Nowa Wieś (powstała z połączenia części gminy Konopnica i Radoszewice spod okupacji niemieckiej), która de facto przestała istnieć wraz z przyłączeniem tych części gmin. Jednakże w statystyce wyborczej opracowanej dla pierwszych wyborów parlamentarnych z 26 stycznia 1919 r. funkcjonowała ona nadal. Natomiast Antoni Zaczyński, który został pisarzem gminnym gminy Nowa Wieś w kwietniu 1918 r. w kwestionariuszu osobowym 
Od tego momentu Wieluńskie obejmowało miasto powiatowe Wieluń oraz Praszkę i Wieruszów (którym prawa miejskie przywrócił okupant niemiecki w 1917 r.) oraz 25 gmin wiejskich: Bolesławiec, Chotynin, Czastary, Działoszyn, Dzietrzkowice, Galewice, Kamionka, Kiełczygłów, Konopnica, Kurów, Kuźnica Grabowska, Lututów, Mierzyce, Mokrsko, Naramice, Praszka, Radoszewice, Rudniki, Siemkowice, Skomlin, Skrzynki, Skrzynno, Sokolniki, Starzenice i Wydrzyn ${ }^{11}$. Natomiast dekretem z 4 lutego 1919 r. prawa miejskie zostały potwierdzone dla wszystkich trzech miast ${ }^{12}$.

Powiat wieluński liczył 2106,9 $\mathrm{km}^{2}$, aczkolwiek w pierwszych opracowaniach statystycznych podawano, że było to $2101 \mathrm{~km}^{2}$, co wynikało z faktu braku dokładnych pomiarów tego obszaru. W początkach dwudziestolecia określano jego wielkość na $2113 \mathrm{~km}^{2}$; podobnie było w statystyce rolniczej na początku lat 30., gdy wartość tę uściślano na 211384 ha $\left(2113,84 \mathrm{~km}^{2}\right)^{13}$.

Liczba mieszkańców, według zestawienia sporządzonego przez Wydział Powiatowy $\mathrm{w}$ Wieluniu na potrzeby Urzędu Wojewódzkiego w Łodzi z 22 marca 1920 r., miała wynosić 201 282 ${ }^{14}$. Natomiast w czasie pierwszego powszechnego spisu z 30 września 1921 r. powiat zamieszkiwało 181361 osób $^{15}$. W czasie drugiego powszechnego spisu z 9 grudnia 1931 r. było to już

podał, że gmina została zlikwidowana w kwietniu 1919 r., a on został przeniesiony na analogiczne stanowisko do Konopnicy. Zob.: APŁOS, SPW, sygn. 2807, bp. Kwestionariusz osobowy A. Zaczyńskiego z dn. 9 IX 1919 r.

${ }^{11}$ Skorowidz gmin Rzeczypospolitej Polskiej. Ludność i budynki na podstawie tymczasowych wyników drugiego powszechnego spisu ludności z dn. 9 XII 1931 r. oraz powierzchnia ogólna i użytki rolne. Część I. Województwa centralne i wschodnie, Warszawa 1933, s. 23; Skorowidz miejscowości Rzeczypospolitej Polskiej opracowany na podstawie wyników pierwszego powszechnego spisu ludności $z$ dn. 30 września 1921 r. i innych źródet urzędowych. T. II: województwo łódzkie, Warszawa 1925, s. 124-136; Spis gmin miejskich i wiejskich Rzeczypospolitej Polskiej, oprac. przez J. Scheinkönig i J. Kowalczewskiego, Warszawa 1934, s. 84; M. Bandurka, Zmiany administracyjne i terytorialne ziem województwa łódzkiego w XIX i XX wieku, Łódź 1995, s. 85; T. Olejnik, Praszka w latach..., s. 328; J. Książek, Powiat wieluński w latach 1918-1939, "Rocznik Wieluński” 2001, t. I, s. 113.

12 Dekret o samorzadzie miejskim, Dziennik Praw Państwa Polskiego 1919, nr 13, poz. 140; Dekret o samorzadzie miejskim, [w:] R. Szwed, Samorząd terytorialny w Polsce w latach 1918-1939. Wybór materiałów źródłowych, Częstochowa 2010, s. 30-43; M. Bandurka, dz. cyt., s. 92.

${ }^{13}$ Właściwie 2100,95 km². Zob.: Archiwum Państwowe w Łodzi (dalej: APŁ), Urząd Wojewódzki Łódzki (dalej: UWŁ), sygn. 2704a, k. 2. Zestawienie danych statystycznych o powiatach województwa łódzkiego na dn. 30 III 1922 r.; Rocznik statystyki Rzeczypospolitej Polskiej 1920/21, r. 1, cz. 1, Warszawa 1921, s. 35; Pierwszy powszechny spis Rzeczypospolitej Polskiej z dnia 30 września 1921 roku. Gospodarstwa wiejskie: województwa centralne, Warszawa 1928, s. XXII; Statystyka Rolnicza 1930/1931, „Statystyka Polski”, Serja B, z. 1, Warszawa 1932, s. 19; Kalendarz Informator na Województwo Łódzkie na rok 1922, Łódź [1922], s. 67, 80.

${ }^{14}$ APŁ, UWŁ, sygn. 2645, bp. Wykaz miejscowości powiatu wieluńskiego z liczbą ludności na dn. 22 III $1920 \mathrm{r}$.

${ }^{15}$ Pierwszy powszechny spis Rzeczypospolitej Polskiej z dnia 30 września 1921 roku. Mieszkania. Ludność. Stosunki zawodowe. Województwo tódzkie, Warszawa 1928, s. 3; Kalendarz Skarbowy na rok 1928, s. 26. 


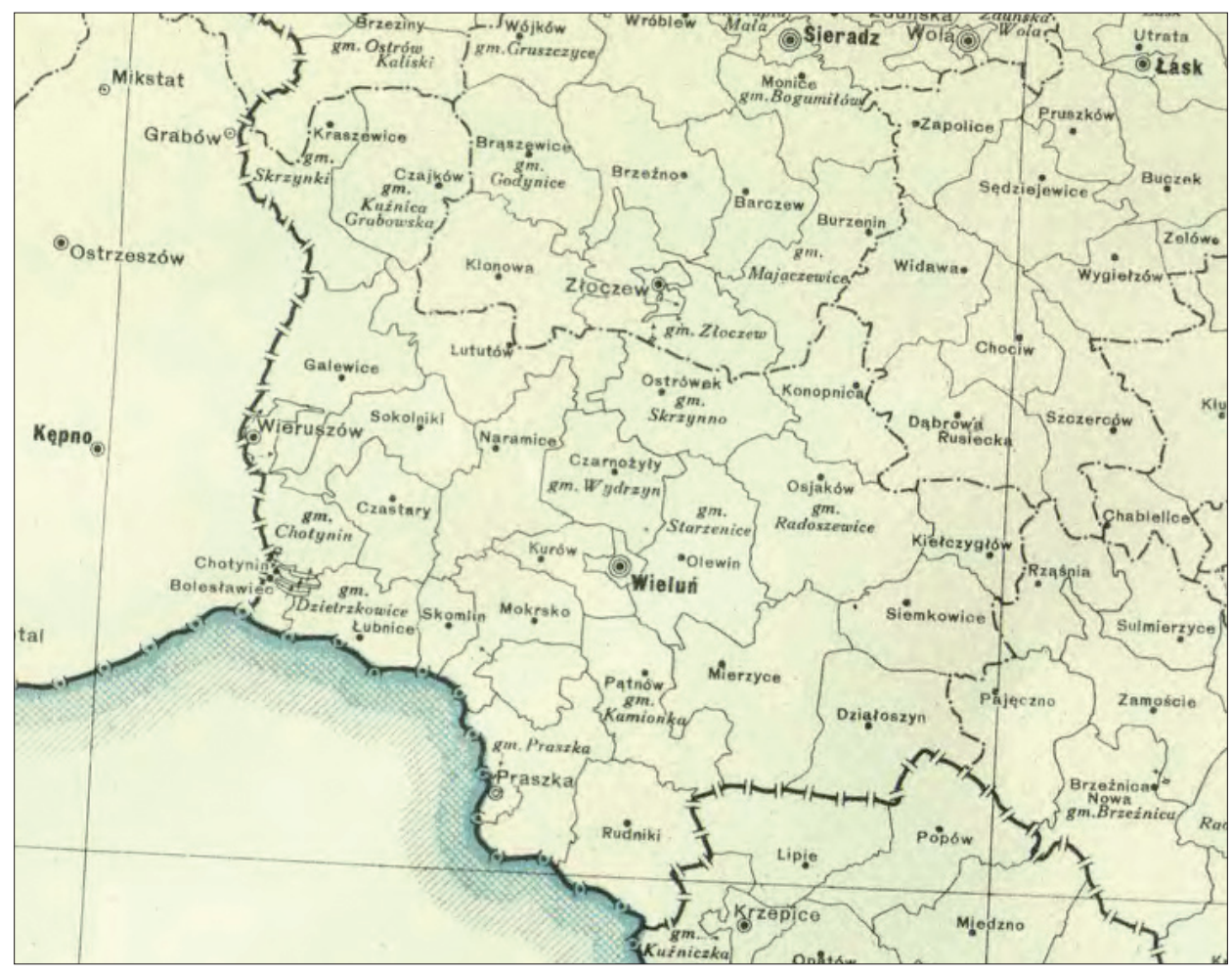

Mapa nr 1. Powiat wieluński w okresie międzywojennym

Źródło: Fragment mapy: Województwa centralne i wschodnie Rzeczpospolitej Polskiej. Podziat na gminy wedtug stanu z dnia 1. IV $1933 r$.

$214299^{16}$, natomiast 1 stycznia 1939 r. - 235470 osób ${ }^{17}$, a więc od 1921 r. przybyło 54109 mieszkańców (+29,84 proc.).

Większość mieszkańców zamieszkiwało wieś: w 1921 r. było to 88,80 proc. mieszkańców, w 1931 - 89,17 proc., a 1 stycznia 1939 r. $-89,07$ proc. ${ }^{18}$ Tym samym dominowało rolnictwo, w czasie pierwszego powszechnego spisu bowiem stanowiło ono miejsce pracy i utrzymania dla 80,39 proc. mieszkańców (razem z leśnictwem, hodowlą, ogrodnictwem i rybactwem) ${ }^{19}$. W kolejnych

${ }^{16}$ Drugi powszechny spis ludności z dn. 9. XII 1931 r. Mieszkania i gospodarstwa domowe. Ludność. Stosunki zawodowe. Województwo łódzkie bez miasta Łodzi, Warszawa 1938, s. 1.

17 APŁOS, SPW, sygn. 861, k. 12 Powiatowa księga narodowościowa powiatu wieluńskiego z 1939 r.

18 Tamże; Skorowidz miejscowości..., s. 124-136; Drugi powszechny spis ludności z dn. 9. XII 1931 r. Mieszkania i gospodarstwa domowe. Ludność. Stosunki zawodowe. Województwo tódzkie..., s. 1.

19 Pierwszy powszechny spis Rzeczypospolitej Polskiej z dnia 30 września 1921 roku. Mieszkania. Ludność. Stosunki zawodowe. Województwo..., s. 195-197. 
latach struktura zawodowa i źródła utrzymania nie ulegały większym zmianom, bowiem 9 grudnia 1931 r. z rolnictwa utrzymywało się 79,99 proc. mieszkańców ${ }^{20}$. Dane zaś na 1 stycznia 1938 r. wskazują, że rolników i robotników rolnych żyjących z tego działu było 178418 (75,97 proc.); osobno sklasyfikowani byli bezrobotni robotnicy rolni i ich rodziny - 17688 osób (7,53 proc.). Nie wiadomo, ilu pracowników umysłowych pracowało dla rolnictwa (np. kancelarzyści w majątkach ziemskich), jednakże nie było ich zbyt wielu ${ }^{21}$.

Część granicy powiatu wieluńskiego, czyli odcinek południowo-zachodni o długości $52 \mathrm{~km}$, jednocześnie stanowił granicę państwową polsko-niemiecką, z czego $7 \mathrm{~km}$ była to granica tzw. „sucha”, a $45 \mathrm{~km}$ to granica biegnąca na rzece Prośnie, „która tuż przy granicy na Śląsku Pruskim bierze początek i płynie wąskim strumykiem, a dopiero od wsi Prosna w powiecie Wieluńskim przybiera na masie wodnej"22. Przy granicy państwowej leżały gminy: Chotynin, Dzietrzkowice, Skomlin, Mokrsko, gmina Praszka, miasto Praszka i Rudniki, które graniczyły z powiatami: Rosenberg (Olesno) i Kreuzburg (Kluczbork) w Niemczech ${ }^{23}$.

Specyfika, jakiej nabierał z czasem powiat wieluński i jaką utrzymał w czasie II RP, wynikała z nadgranicznego położenia: najpierw nad granicą rosyjsko-pruską (niemiecką), a następnie nad polsko-niemiecką. W 1936 r. starosta mgr Tadeusz Niżankowski stwierdzał: „Bliskość granicy ułatwia trwającą tu lat zgórą 40 emigrację sezonową do Niemiec kierując tam rokrocznie około 30.000 osób” 24 . Jednocześnie: „Ten typ proletarjatu wiejskiego zaludnił stopniowo powiat wieluński jeszcze za dawnych czasów zaboru rosyjskiego. Tutaj, jako do powiatu granicznego napływała rokrocznie masa robotników rolnych, którzy mając możność otrzymywania przepustek zagranicznych udawali się na letnie i jesienne roboty do ościennych Niemiec, a po ukończeniu robót powracając nie opuszczali już terenów powiatu wieluńskiego,

${ }^{20}$ Drugi powszechny spis ludności z dn. 9. XII 1931 r. Mieszkania i gospodarstwa domowe. Ludność. Stosunki zawodowe. Województwo tódzkie..., s. 67.

${ }^{21}$ APŁ, Akta miasta Łodzi, sygn. 23 670, k. 3 Struktura zatrudnienia ludności powiatu wieluńskiego na dn. 1 I $1938 \mathrm{r}$.

${ }^{22}$ APŁOS, SPW, sygn. 767, k. 83 Informacja starosty wieluńskiego (dalej: SWi) o stanie rolnictwa w powiecie wieluńskim. Podobnie: S. Borawski, Rolnictwo w powiecie wieluńskim. Dane statystyczne i uwagi krytyczne, "Głos Polski” z 23 lipca 1929, nr 199, s. 4. Natomiast 43 km (w tym 7 km suchej): Ziemiaństwo - Rolnictwo - Samorządy województwa łódzkiego, t. 1, pod red. Z. Kotkowskiego i S. Grodzieńskiego, Łódź 1928, s. 130.

${ }^{23}$ APŁOS, SPW, sygn. 788, k. 4 Sprawozdanie SWi o stanie powiatu wieluńskiego za 1936 r.; Województwa centralne i wschodnie Rzeczypospolitej Wschodniej. Podział na gminy wedtug stanu z dnia 1. IV 1933 roku; Mapa gmin Rzeczypospolitej Polskiej. Podział administracyjny wedtug stanu z dnia 1. IV 1938 roku.

${ }^{24}$ APŁOS, SPW, sygn. 788, k. 4 Sprawozdanie SWi o stanie powiatu wieluńskiego za $1936 \mathrm{r}$. 
a spędzała dwa - trzy zimowe miesiące, by z nastaniem wiosny udać się z powrotem do Niemiec; stąd powstało chałupnictwo bezrolnych" 25 .

Sytuacja gospodarcza, jaka panowała w powiecie wieluńskim w międzywojniu, zachęcała, ale także zmuszała do szukania pracy za granicą. Rolnictwo, będące podstawowym źródłem zatrudnienia oraz utrzymania, było dwubiegunowe i mocno rozdrobnione. W 1921 r. istniały 24538 gospodarstwa o łącznej powierzchni 180728 ha, przy czym gospodarstwa do 5 ha w liczbie 13789 (56,19 proc. wszystkich) obejmowały 35058 ha (19,40 proc. ziemi), a gospodarstwa powyżej 50 ha w liczbie 91 (0,37 proc.) miały 54860 ha $(30,36 \text { proc. })^{26}$. Przed wojną w lipcu 1939 r. w powiecie wieluńskim było 43245 gospodarstw, w tym do 2 ha - 14250 (32,95 proc. wszystkich); 2-5 ha - 17440 (40,33 proc.); $5-10$ ha - 9820 (22,71 proc.); $10-20$ ha - 1520 (3,51 proc.); $20-50$ ha 155 (0,36 proc.) i powyżej 50 ha - $60(0,14 \text { proc. })^{27}$. Widać zatem, że struktura gospodarstw ulegała systematycznemu pogorszeniu, najwięcej bowiem przybywało najmniejszych gospodarstw, które nie były w stanie zaspokoić potrzeb gospodarza i jego rodziny, zwłaszcza że liczba ludności wiejskiej systematycznie wzrastała.

Innym problemem był brak przemysłu, który mógłby wchłonąć nadwyżki siły roboczej. Wystarczy stwierdzić, że w takim rozległym powiecie był tylko jeden duży zakład przemysłowy, a mianowicie cukrownia we wsi Niedzielsko, zatrudniająca po I wojnie ok. 40 pracowników stałych i 300 w sezonie, podczas gdy kolejne trzy największe zakłady, czyli tartaki parowe, miały tylko po kilkunastu pracowników ${ }^{28}$. Natomiast pozostałe działy gospodarki były słabo rozwinięte i nie były w stanie wchłonąć nadwyżki siły roboczej $^{29}$.

Trudna sytuacja gospodarcza powodowała, że od zarania niepodległości pojawiło się na tym obszarze bezrobocie; już w czerwcu 1919 r. zarejestrowanych było 7580 osób, w tym największą grupę stanowili robotnicy rolni (5610) i robotnicy fabryczni (1148) oraz młodzież do lat osiemnastu: 463 osób do robót rolnych i 6 do robót fabrycznych ${ }^{30}$. Zapewne faktyczna liczba bezrobotnych, nie tylko w pierwszych latach, ale i później, była wyższa niż ta

${ }^{25}$ APŁOS, SPW, sygn. 172, k. 80 Pismo SWi do MPiOS - Urząd Emigracyjny z dn. 20 V $1927 \mathrm{r}$.

${ }^{26}$ Pierwszy powszechny spis Rzeczypospolitej Polskiej z dnia 30 września 1921 roku. Gospodarstwa wiejskie..., s. 11.

${ }^{27}$ K. Rybczyński, Charakterystyka społeczno-ekonomiczna ziemi wieluńskiej w okresie międzywojennym, [w:] 30 lat wieluńskiego rolnictwa, Wielun 1974, s. 12.

${ }^{28}$ APŁOS, SPW, sygn. 69, Wykaz zakładów przemysłowych; APŁOS, SPW, sygn. 70, Wykaz zakładów przemysłowych.

${ }^{29}$ M. Michalski, Powiat wieluński w okresie międzywojennym (1918-1939), Łódź 2017, k. 311364. Rozprawa doktorska napisana w Katedrze Historii Polski Najnowszej Instytutu Historii UŁ pod kierunkiem prof. dr. hab. Kazimierza Badziaka; w zbiorach autora.

30 320, DUKRPPW 20 VI 1919, nr 22, s. 196-197. 
zarejestrowana, część bezrobotnych bowiem nie rejestrowała się - nie rejestrowano osób, które nigdy nie pracowały (np. młodzieży) czy reemigrantów ${ }^{31}$. Inną kwestią było zjawisko tzw. względnego przeludnienia wsi, czyli nadmiaru ludzi w gospodarstwach chłopskich, występujące zwłaszcza w gospodarstwach karłowatych, których przez cały omawiany okres przybywało, a ich użytkownicy nie mogli się rejestrować jako bezrobotni ${ }^{32}$. Bezrobocie w różnym natężeniu występowało przez cały czas, oprócz roku 1926, gdy emigracja sezonowa do Niemiec była rekordowo najwyższa, a część mieszkańców znalazła pracę przy budowie linii kolejowej Kalety-Herby-WieluńPodzamcze ${ }^{33}$. Najtrudniejsza sytuacja nastąpiła w czasie wielkiego kryzysu. I tak przykładowo 30 listopada 1933 r. było 20511 bezrobotnych osób ${ }^{34}$.

Wszystkie powyższe warunki powodowały, że obszar powiatu wieluńskiego, podobnie jak przed I wojną światową, stał się idealną bazą ludnościową dla emigracji sezonowej do zachodniego sąsiada.

\section{Nielegalna emigracja sezonowa z lat 1918-1925}

W pierwszych latach po wojnie, mimo że Niemcy oficjalnie zgłaszały zapotrzebowanie na polskich pracowników sezonowych, polskie władze zakazały wyjazdu do Republiki Weimarskiej do czasu podpisania układu emigracyj-

${ }^{31}$ H. Jędruszczak, Płace robotników przemystowych w Polsce w latach 1924-1939, Warszawa 1963, s. 124-125; Z. Landau, J. Tomaszewski, Trudna niepodległość. Rozważania o gospodarce Polski 1918-1939, Warszawa 1978, s. 99-100; Z. Landau, Bezrobocie, [w:] Encyklopedia historii gospodarczej Polski do 1945 r.: A-N, red. naczelny A. Mączak, Warszawa 1981, s. 32-33.

${ }^{32}$ W. Roszkowski podaje, że szacunkowe przeludnienie agrarne wynosiło: w $1921 \mathrm{r}$. 4,5 mln, w 1931 - 4,7 mln i w 1938 - 5,5 mln; według Zdzisława Ludkiewicza: w 1921 r. - ponad 2 mln ludzi; w 1935 r. Instytut Gospodarstwa Społecznego oceniał zjawisko na 4,5 mln z tego 2,4 mln osób mogły natychmiast opuścić wieś bez wpływu na wielkość i jakość produkcji rolnej, a natomiast ekonomista Józef Poniatowski oceniał na od 6 do 9 mln osób. Według M. Drozdowskiego, w 1939 r. 5300 tys. osób zawodowo czynnych, a wraz z ludnością zawodowo bierną 8480 tys. Zob.: L. Landau, J. Pański, E. Strzelecki, Bezrobocie wśród chtopów, Warszawa 1939; Wieś w liczbach w Polsce burżuazyjno-obszarniczej i w Polsce Ludowej, Warszawa 1954, s. 96-97; M. Drozdowski, Polityka gospodarcza rządu polskiego 1936-1939, Warszawa 1963, s. 200; W. Ruciński, Rozwój gospodarczy ziem polskich w zarysie, Warszawa 1963, s. 355; Z. Landau, Gospodarka polska w latach 1918-1939, [w:] B. Zientara, A. Mączak, I. Ihnatowicz, Z. Landau, Dzieje gospodarcze Polski do 1939 r., Warszawa 1965, s. 482; Z. Landau, J. Tomaszewski, Trudna niepodległość..., s. 115; W. Roszkowski, Rolnictwo i leśnictwo, [w:] Problemy gospodarcze Drugiej Rzeczypospolitej, red. K. Kozłowski, Warszawa 1989, s. 104; Z. Landau, J. Tomaszewski, Gospodarka Drugiej Rzeczypospolitej, Warszawa 1991, s. 11.

${ }_{33}$ APŁOS, SPW, sygn. 167, k. 4 Sprawozdanie sytuacyjne SWi za luty 1926 r.; Nowa kolej na Górny Śląsk, „Głos Ziemi Wieluńskiej” z 21 marca 1926, nr 12, s. 15.

${ }^{34}$ APŁOS, SPW, sygn. 99a, k. 85 Sprawozdanie sytuacyjne SWi z ruchu wywrotowego, zawodowego i bezpieczeństwa [dalej: RWZB] za listopad $1933 \mathrm{r}$. 
nego. W tej sytuacji robotnicy wyjeżdżali nielegalnie przez zieloną granicę ${ }^{35}$, co podkreślał np. burmistrz Wieruszowa Leonard Rojewski, stwierdzając, że „płakać się chce patrząc na ten tułaczy młodociany lud, skradający się cichaczem, najczęściej nocami, ażeby przemycić się przez granicę do Niemiec za zarobkiem [...]"36. Tym samym dla pierwszych lat urzędowe statystyki podają tylko po kilkudziesięciu robotników sezonowych, którzy legalnie wyjechali do pracy ${ }^{37}$. Natomiast liczbę emigrantów nielegalnych dla okresu 1919-1925 strona polska oceniała na około 100000 osób rocznie, a ruch odbywał się „przy daleko posuniętej tolerancji naszych władz [...] przez zieloną granicę" ${ }^{38}$. Z kolei na podstawie liczby wydawanych przez Niemiecką Centralę Robotniczą (NCR) (Deutsche Arbeiterzentrale) legitymacji wiadomo, że w 1919 r. było to 112663 pracowników, a w następnych latach liczba ta oscylowała na podobnym poziomie: 1920 - 126 148; 1921 - 113 056; 1922 - 127 711; 1923 - 103 540; 1924 - 96 948; 1925 - 125 790; 1926 - 114255 i w 1927 r. - $110741^{39}$.

Jednocześnie po stronie niemieckiej prowadzono dwutorową politykę, gdyż z jednej strony sprzeciwiano się lub ograniczano imigrację z Polski, a z drugiej - Ministerstwo Spraw Wewnętrznych (MSW) (Reichsministerium des Innern) Niemiec wydało np. okólnik z 21 lipca 1923 r., w którym stwierdzano: „Przekroczenie granicy przez te osoby winno się odbyć z pominięciem granicznej kontroli polskiej, gdyż rząd polski przeciwny jest wyjeżdżaniu sił roboczych do Niemiec. Wskutek tego obcy robotnicy nie muszą posiadać jakichkolwiek dowodów osobistych czy dokumentów dotyczących ich zwer-

${ }^{35}$ K. Fiedor, Władze niemieckie wobec polskich robotników rolnych w latach 1918-1932, „Śląski Kwartalnik Historyczny Sobótka” 1962, r. XVII, nr 2, s. 206-226; W. Spaleniak, Prawno-polityczne aspekty emigracji sezonowej polskich robotników rolnych do Niemiec w latach 1919-1939, "Annales Univesitatis Mariae Curie-Skłodowska Lubin - Polonia" 2002, Sectio K, vol. 9, s. 48; A. Jarzyna, Polityka emigracyjna, Lwów 1933, s. 87. Zob. o emigracji do Niemiec: J. Tomaszewski, Czynniki wptywające na migracje zewnętrzne ludności w Polsce 1918-1939, [w:] Mechanizmy polskich migracji zarobkowych, pod red. C. Bobińskiej, Warszawa 1976, s. 143-145; E. Kołodziej, Wychodźstwo zarobkowe z Polski 1918-1939: studia nad polityka emigracyjna II Rzeczypospolitej, Warszawa 1982, s. 105-108.

${ }^{36}$ L. Rojewski, Z Wieruszowa. Emigracja młodzieży, „Wielunianin” z 8 marca 1925, nr 10, s. 6.

${ }^{37}$ M. Krasocki, Ruch emigracyjny z Polski w I-em pótroczu 1926 r., "Przegląd Emigracyjny” 1926, nr 1, s. 6. Oficjalne dane wskazują na: 1922 - 34; 1923 - 17; 1924 - 80 i 1925 - 266. Zob.: Rocznik Statystyki Rzeczypospolitej Polskiej 1925/1926, r. 4, Warszawa 1927, s. 99; M. Pankiewicz, Problem emigracji w Polsce, Warszawa 1935, s. 14. Dla roku 1922 występuje także wartość 41. Zob.: A. Zarychta, Emigracja polska 1918-1931 i jej znaczenie dla państwa, Warszawa 1933, tabela III.

38 A. Jarzyna, dz. cyt., s. 92. Zob. także: M. Pankiewicz, dz. cyt., s. 12, 18. Emigracja z województwa łódzkiego w latach 1925-1929 została już opracowana, lecz w artykule nie wykorzystano podstawowej literatury, nie wspominając już o źródłach archiwalnych. Zob.: A. Rzepkowski, Emigracja europejska i pozaeuropejska z województwa łódzkiego w 2. połowie lat 20. XX w. oraz jej skład wyznaniowy i narodowościowy, „Rocznik Łódzki” 2014, t. 61, s. 195-205.

39 A. Jarzyna, dz. cyt., s. 92. 
bowania. Należy poinstruować urzędników, którym podlega kontrola granicy, że spotkanych przy przekroczeniu granicy osób, którym można uwierzyć, że zostały zwerbowane do robót polnych w Niemczech, po stwierdzeniu ich personalnych danych nie należy przekazywać władzom policyjnym, lecz najbliższemu posterunkowi granicznemu Niemieckiej Centrali Robotniczej" 40 .

W przypadku Wieluńskiego, emigracja w pierwszym okresie po wojnie zapewne była nieco mniejsza niż w następnych latach, co wynikało stąd, że część mężczyzn była w wojsku w związku z walkami o granice, sytuacja polityczna była niepewna, a także $z$ faktu ożywienia gospodarczego po I wojnie światowej ${ }^{41}$. Zapewne także nielegalność przekraczania granicy powodowała, że nie każdy chciał ryzykować. Jednakże w 1923 r., kiedy gospodarka polska popadła w kryzys w związku z narastającą inflacją i hiperinflacją, wyjechało ok. 40 tysięcy osób ${ }^{42}$, czyli zapewne większość chętnych. Jednakże nie był to udany rok dla robotników, w Niemczech bowiem panowała hiperinflacja przekraczająca znacznie polską, tak że do Polski powracali tacy, którzy mieszkali tam po 10-12 lat, nie mogli bowiem wyżywić swoich rodzin. Części robotników nie było nawet stać na opłacenie w konsulacie przepustki na powrót do $\mathrm{kraju}^{43}$, a do tego dochodziło jeszcze często trzydniowe oczekiwanie na nią, co przy hiperinflacji pochłaniało oszczędności. Bywały przypad-

${ }^{40}$ Cyt. za: W. Spaleniak, Prawno-polityczne..., s. 54-55.

${ }^{41}$ A. Zarychta stwierdził: „Pierwsze dwa lata niepodległości (1918 i 1919) posiadają najmniejsze liczby emigrantów. Wynika to nie tylko z powodów niedostatecznie prowadzonej statystyki. Powodem i to na pewno poważniejszym była również wojna, niepewność stosunków, chaos ogólny, kształtujące się nowe organizmy społeczne i państwowe, naturalna wyczekująca postawa ludności, która z powstającym państwem łączyła nowe nadzieje, trwając na starych miejscach, na których ją nowe warunki życia zastały". Zob.: A. Zarychta, dz. cyt., s. 11.

42 J. Milczarek, dz. cyt., s. 19. Kurs dolara amerykańskiego w Polsce wynoszący 31 stycznia 1923 r. 35650 mkp spadł 31 grudnia 1923 r. do 6375000 mkp, a obieg pieniężny zwiększył się z 909160000000 do 125371955000000 mkp! Zob.: J. Zdziechowski, Finanse Polski w latach 19241925, Warszawa 1925, s. 14-15; Z. Landau, J. Tomaszewski, W dobie inflacji 1918-1923, Warszawa 1967, s. 280; M.M. Drozdowski, Życie gospodarcze Polski w latach 1918-1939, [w:] Z dziejów Drugiej Rzeczypospolitej, pod red. A. Garlickiego, Warszawa 1986, s. 154; M. Łapa, Modernizacja państwa. Polska polityka gospodarcza 1926-1929, Łódź 2002, s. 21; W. Morawski, Od marki do złotego. Historia finansów Drugiej Rzeczypospolitej, Warszawa 2008, s. 76; C. Leszczyńska, Polska polityka pieniężna $i$ walutowa w latach 1924-1936 w systemie Gold Exchange Standard, Warszawa 2013, s. 81. Tymczasem w Niemczech w maju 1923 r. dolar kosztował 50000 mk, w początkach sierpnia 1000000 mk, w październiku już ponad 50000000000 mk, natomiast w listopadzie 4200000000000 mk, a wprowadzona 15 listopada tzw. marka rentowa (Rentenmark) wymieniana była w relacji 1:1 000000000000 mk. Zob.: A. Dudek, Republika Weimarska - kryzys i stabilizacja, [w:] Historia polityczna świata XX wieku 1901-1945, pod red. M. Bankowicza, Kraków 2004, s. 189.

${ }^{43}$ APŁOS, SPW, sygn. 99a, k. 3 Sprawozdanie informacyjno-policyjne [dalej: SIP] nr 2 SWi za sierpień 1923 r. Zob. także: T. Olejnik, W Polsce odrodzonej (1918-1939), [w:] Nad górna..., s. 339 . 
ki, że robotnicy wracali „obdarci i wynędzniali”, gdyż musieli sprzedać swoją odzież na pokrycie kosztów podróży ${ }^{44}$ lub szli na pieszo ${ }^{45}$.

W 1924 r. na podstawie informacji zebranych przez NCR, które dotyczyły poprzedniego miejsca zamieszkania, pracowało w Niemczech 101985 robotników rolnych, w tym z województwa łódzkiego 50988 (50 proc. wszystkich), a z powiatu wieluńskiego 24233 osoby (23,76 proc.), czyli prawie tyle, co z całego województwa kieleckiego - 24425 osób, a także kilka razy więcej niż z krakowskiego (4552) czy z warszawskiego (4140) ${ }^{46}$, a Wieluńskie ponownie, tak jak przed wojną, było największym dostarczycielem siły roboczej w skali powiatowej z Polski do Republiki Weimarskiej.

\section{Legalna emigracja sezonowa w latach 1926-1931}

Nieuregulowanie emigracji sezonowej nie mogło trwać bez końca i 12 stycznia 1926 r. zawarto pierwsze prowizoryczne porozumienie sprowokowane interesami gospodarczymi obu stron ${ }^{47}$, o którym dr Tadeusz Dalbor, radca emigracyjny przy Ambasadzie Polskiej w Berlinie, powiedział na posiedzeniu Państwowej Rady Emigracyjnej: „tymczasowe porozumienie, zawarte 12 stycznia 1926 r. dało korzystne wyniki, pozwoliło bowiem do pewnego stopnia uregulować dotychczasowy «dziki» i chaotyczny ruch emigracyjny. Na podstawie układu weszło do Niemiec legalnie 49000 robotników sezonowych bez których, według ustalającego się coraz bardziej w Niemczech przekonania, zbiory byłyby znacznie utrudnione, a w wielu wypadkach, jak np. zbiór buraków wprost niemożliwe" 48 .

${ }^{44}$ APŁOS, SPW, sygn. 99a, k. 11 SIP nr 4 SWi za październik 1923 r.

45 Tamże, k. 8 SIP nr 3 SWi za wrzesień 1923 r.; k. 18 SIP nr 5 SWi za listopad 1923 r.

${ }^{46}$ Ruch migracyjny, warunki pracy $i$ produkcji w obcych krajach, „Biuletyn Urzędu Emigracyjnego" 1925, nr 9-11, s. 38.

${ }^{47}$ Mianowicie Polska zgodziła się na wydanie paszportów emigracyjnych określonemu kontygentowi sezonowców, Niemcy zaś na zredukowanie liczby przymuszonych repatriantów i powrót ich do Polski etapami. Organizacją emigracji miały się zajmować wyłącznie PUPP i NCR. Zob.: Wychodztwo sezonowe do Niemiec, „,Robotniczy Przegląd Gospodarczy” marzec 1926, nr 3, s. 58; L. Kulczycki, Prowizoryczna umowa polsko-niemiecka w sprawie emigracji, „Przegląd Polityczny" 1927, z. 3/4, s. 123; M. Szawleski, Kwestja emigracji w Polsce, Warszawa 1927, s. 124; Z. Landau, J. Tomaszewski, Od Grabskiego do Piłsudskiego. Okres kryzysu poinflacyjnego i ożywienia koniunktury 1924-1929, Warszawa 1971, s. 12; K. Groniowski Emigracja, [w:] Encyklopedia historii..., s. 162; H. Janowska, Emigracja z Polski w latach 1918-1939, [w:] Emigracja z ziem..., s. 359.

${ }^{48}$ Nadzwyczajne posiedzenie Państwowej Rady Emigracyjnej z dnia 1 września 1926 r., „Przegląd Emigracyjny" 1926, z. 3/4, s. 115. Zob. także: Komunikat z dn. 23 grudnia 1926 r. w sprawie emigracji do Niemiec, „Przegląd Emigracyjny” 1926, z. 3/4, s. 177. Zob. o problemach w negocjacjach oraz o szczegółach poszczególnych umów z 1926 i 1927 r.: E. Kołodziej, Wychodźstwo zarobkowe..., s. 160-163. 
W przełomowym 1926 r. w powiecie wieluńskim już pod koniec stycznia do starostwa zaczęli zgłaszać się pierwsi robotnicy wnioskujący o wydanie im przepustek na wyjazd do Niemiec i dowodów osobistych krajowych. Początkowo starostwo nie wydawało stosownych dokumentów, ale także strona niemiecka nie chciała przyjmować robotników sezonowych, stwierdzając, że będą oni angażowani do pracy od 1 lutego. Po tej dacie zjawili się w Zawisnej (miasto obok Praszki, po niemieckiej stronie) w poszukiwaniu robotników pierwsi gospodarze niemieccy. Ponieważ starostwo nadal nie wydawało odpowiednich dokumentów, robotnicy starali się nielegalnie przekraczać granicę ${ }^{49} .8$ lutego w Wieluniu i 16 lutego w Praszce otwarto ekspozytury Państwowego Urzędu Pośrednictwa Pracy (PUPP). Jednakże placówka w Praszce, składająca się zaledwie z jednego urzędnika, okazała się bezużyteczna. Natomiast Biuro Pośrednictwa Pracy w Wieluniu i zorganizowane przez starostwo biuro wydawania paszportów liczyło wówczas dziewięć osób. Do 1 marca urzędy gminne zarejestrowały 24632 robotników chętnych do wyjazdu, paszportów zaś wydano tylko 2745 . Urzędnicy starostwa przyjmowali ponad sto osób dziennie, jednakże praca była utrudniona i trwała od godziny 8.00 do 19.00, wskutek żądań strony niemieckiej, aby wydawać tylko paszporty osobom, na które wyrażono zapotrzebowanie w Niemczech. Wobec tego, że wielu pracowników kontraktowych nie przybyło na czas, zamiast 2000 zgłoszonych przez stronę niemiecką, przeszło tylko kilkudziesięciu. Dopiero po 20 lutego, zaczęli na szerszą skalę przybywać pracownicy kontraktowi i wtedy nastąpiło przyspieszenie wydawania paszportów ${ }^{50}$. Nie brakowało od samego początku pewnych nadużyć, gdyż jak komunikował starosta: „[...] w końcu lutego i początkach marca, gdy ruch legalny robotników sezonowych był słaby, Niemcy przyjmowali przechodzących nielegalnie przez granicę robotników, a nawet zachęcali ustnie i pisemnie do przechodzenia nielegalnie granicy. Część robotników, którzy przeszli granicę Niemcy wyrzucili każąc im przejść «zieloną granicę» z powrotem (do 1000 robotników partjami do 200 osób)" ${ }^{51}$.

Natomiast ze strony polskiej doszło do innej, cennej inicjatywy dotyczącej pewnego unormowania ruchu granicznego, którą podjęto na zjeździe starostów województwa łódzkiego 14 lutego 1926 r. W wyniku przeprowadzonej dyskusji zaproponowano, by starosta wieluński zasięgał informacji u pogranicznych władz niemieckich odnośnie do liczby potrzebnych pracowników z województwa łódzkiego, a sąsiadujące z Wieluńskim starostwa stale informowały władze w Wieluniu, o liczbie zarejestrowanych u nich robotników, którzy mieli udawać się do pracy w Niemczech przez Praszkę. Takie działa-

\footnotetext{
${ }^{49}$ APŁOS, SPW, sygn. 167, k. 1 Sprawozdanie sytuacyjne SWi za styczeń 1926 r.

${ }^{50}$ Tamże, k. 3 Sprawozdanie sytuacyjne SWi za luty $1926 \mathrm{r}$.

${ }^{51}$ Tamże, k. 5 Sprawozdanie sytuacyjne SWi za marzec 1926 r.
} 
nie miało na celu uniknięcie nadmiaru robotników gromadzących się na granicy, gdyby starosta wieluński miał informacje o tym, ilu faktycznie potrzeba ludzi ${ }^{52}$. Zaproponowany pomysł dość szybko wprowadzono w życie, gdyż już 9 kwietnia 1926 r. Wydział Bezpieczeństwa Publicznego w Łodzi informował starostwa powiatowe, aby wstrzymały wyjazdy pracowników sezonowych poprzez Praszkę, gdyż znajdowało się tam już 2000 osób, a Niemcy przepuszczali tylko po 200 osób dziennie ${ }^{53}$.

Szczyt wydawania paszportów przypadł na okres od 1 do 20 marca, gdy wydano ich 17 200. Zwiększenie liczby wydawanych dokumentów powodowało, że stale zwiększała się liczba osób przekraczających granicę, wynosząc od 200 do nawet 2000 dziennie. Mimo tego codziennie rosła także kolejka osób czekających na przekroczenie granicy, tak że w dniach 18, 19 i 20 marca w Zawiśnie czekało około 2000 osób, a w Praszce około 5000 osób. W tym samym czasie, bo 15 marca, strona niemiecka poprosiła o wstrzymanie wychodźstwa Polaków do 22 marca, a następnie do 4 kwietnia. Doszło także do kolejnej manipulacji ze strony niemieckiej, gdyż tamtejsi urzędnicy wprowadzili robotników w błąd, przyjmując po kilka osób na jedno miejsce, toteż robotnikom po przekroczeniu granicy polsko-niemieckiej zawarte uprzednio kontrakty unieważniano i musieli oni wracać do Polski. Łącznie w marcu granicę przekroczyło 15021 robotników ${ }^{54}$. W kolejnych dniach zmniejszała się liczba osób przekraczających granicę z ok. 250 osób, po 13 kwietnia do 60 osób. Starostwo wydawało paszporty tylko tym, którzy wykazywali się dokumentem potwierdzającym, że mają zagwarantowaną pracę w Niemczech. Łącznie w kwietniu granicę przekroczyło tylko 2816 osób. Tym samym przeminęła główna fala emigracyjna i można było zrobić pewne podsumowanie w stosunku do 1925 r. Otóż, okazało się, że przez granicę przeszło mniej mężczyzn, gdyż niemieccy pracodawcy zgłosili większe zapotrzebowanie na pracę kobiet. Taka sytuacja spowodowała że: „Pozostało więc w powiecie do dwóch tysięcy młodych ludzi, którzy stale wędrowali do Niemiec, ludzi zdemoralizowanych niechętnych do pracy, gorzej wynagradzanej w kraju, nie-

52 Tamże, k. 83 Protokół spisany w UWŁ z przebiegu i wyniku zjazdu starostów z dn. 14 II 1926 r. Odnotować należy, że także starostwo otrzymywało informację z MSW o spodziewanej liczbie osób, które będą przekraczać granicę w Praszce. I tak dla 1928 i 1929 r. przewidywano ok. 25000 osób, w 1930 r. - 22000 osób, a w 1931 - 9000 osób. Zob.: APŁ, UWŁ, sygn. 201, k. 4 Pismo MSW do m.in. wojewody łódzkiego [dalej: WŁ] z 5 VII 1928 r.; k. 25 Pismo MSW do WŁ. z października 1929 r.; k. 30 Pismo MSW do WŁ. z dn. 19 IX 1930; k. 68 Pismo MSW do WŁ. z dn. 22 IX $1931 \mathrm{r}$.

53 APŁOS, SPW, sygn. 167, k. 107 Pismo z Wydziału Bezpieczeństwa Publicznego [dalej: WBP] UWŁ do starostów województwa łódzkiego z dn. 9 IV 1926 r.

${ }^{54}$ Tamże, k. 5 Sprawozdanie sytuacyjne SWi za marzec 1926 r. 
zadowolonych i przypisujących winę swego pozostania w kraju i bezrobocia władzom rządowym" 55 .

W kolejnych miesiącach 1926 r. przez granicę powiatu wieluńskiego wyjeżdżali już nieliczni robotnicy sezonowi - w maju 366 osób, w tym 258 z powiatu wieluńskiego ${ }^{56}$; w czerwcu 1926 r. 295, w tym 242 z powiatu wieluńskiego oraz nielegalnie ok. stu robotników, którym pracę załatwiła NCR w Rosenbergu (Oleśnie) ${ }^{57}$, w lipcu zaś, w związku ze zbliżającymi się żniwami, wyjechało 939 osób, w tym z Wieluńskiego $854^{58}$. Wyjazdy następowały także jesienią, choćby do prac przy zbiorze buraków cukrowych. We wrześniu granicę przekroczyło 470 osób ${ }^{59}$. Wraz z nastaniem miesięcy jesiennych notowano wzmożone powroty robotników sezonowych do kraju. Brak materiałów archiwalnych nie pozwala przedstawić szczegółowo, jak wyglądała fala powrotów w tymże roku, natomiast wiadomo, że najwięcej osób powróciło w przeciągu od 25 listopada do 25 grudnia, gdy przez przejścia w Praszce i Goli dostało się do kraju 19059 robotników sezonowych ${ }^{60}$. Jednakże jesienią także doszło do zaniedbania ze strony niemieckiej, gdyż „[...] przy powrocie robotników polskich z Niemiec miały istotne miejsce przykre zajścia, należy to przypisać temu, że Niemcy, nie zawiadamiając wcale władz polskich o wysyłce większej liczby robotników, skierowali naraz wielkie masy do Polski, specjalnemi pociągami, które spotkały się po naszej ze zwykłym i oczywiście w tym wypadku niewystarczającym ruchem kolejowym" ${ }^{\prime \prime}$.

W tymże roku dzięki prowizorycznemu porozumieniu z Wieluńskiego wyjechało ok. 40 tysięcy osób ${ }^{62}$. Natomiast z Polski wyemigrowało 167509 osób, w tym do Niemiec 43 706, a do Francji 68 704. Powróciło: 55 559, z tego z Niemiec 36304 osoby, a z Francji 639263. Dodatkowo jeszcze do Niemiec "około 8000 przekroczyło granicę, unikając kontroli władz granicznych"64.

55 Tamże, k. 7 Sprawozdanie sytuacyjne SWi za kwiecień 1926 r.

56 Tamże, k. 9 Sprawozdanie sytuacyjne SWi za maj 1926 r.

57 Tamże, k. 11 Sprawozdanie sytuacyjne SWi za czerwiec 1926 r.

${ }^{58}$ Tamże, k. 18 Sprawozdanie sytuacyjne SWi za lipiec 1926 r.

59 Tamże, k. 58 Sprawozdanie sytuacyjne SWi za wrzesień 1926 r.

${ }^{60}$ Tamże, k. 13 Sprawozdanie miesięczne SWi z ruchu zawodowego, społeczno-politycznego i narodowościowego za okres od 25 XI do 25 XII 1926 r. s. 28.

${ }^{61}$ Sprawy emigracyjne na sejmowej rozprawie budżetowej, „Przegląd Emigracyjny” 1927, z. 1,

${ }^{62}$ Ruch emigracyjny z Polski w 1926 r., „Przegląd Emigracyjny” 1927, z. 1, s. 14-15. Zob. także: W sprawie wychodźstwa robotników sezonowych do Niemiec, "Głos Ziemi Wieluńskiej” z 14 lutego 1926, nr 7, s. 7.

${ }^{63}$ Ruch reemigracyjny do Polski w 1926 r., "Przegląd Emigracyjny” 1927, z. 1, s. 16-17. Zob. także: A. Rzepkowski, dz. cyt., s. 195-205. W przeciągu lat 1927-1938 na emigrację sezonową wyjechało 171,8 tysięcy osób (648,3 osoby na 10000 mieszkańców), a stałą 79,4 tysięcy osób (299,6). Zob.: J. Tomaszewski, Czynniki wptywajace na migracje..., s. 150.

${ }^{64}$ Uwagi do tablic, „Przegląd Emigracyjny” 1927, z. 1, s. 13. 
Kolejnym przełomem w uregulowaniu kwestii emigracji sezonowych robotników, było zawarcie 9 grudnia 1926 r. umowy między Polską a Niemcami. Opracowano wówczas następującą procedurę emigracyjną: w okresie od połowy grudnia do Świąt Bożego Narodzenia NCR miała zawiadamiać Urząd Emigracyjny w Warszawie (UEW) o przypuszczalnym zapotrzebowaniu na robotników rolnych w poszczególnych krajach związkowych i określać te obszary Polski, z których najbardziej pożądani byliby pracownicy. Następnie UEW $w$ porozumieniu z Wydziałem Pośrednictwa Pracy Ministerstwa Pracy i Opieki Społecznej (MPiOS) miał podawać do 15 stycznia NCR powiaty, skąd strona polska przewidywała rekrutację pracowników oraz ich liczbę. Najpóźniej do 1 lutego miało nastąpić spotkanie przedstawicieli NCR i MPiOS w celu ustalenia szczegółów, czyli wysokości kontyngentu, podziału na obwody i technicznej organizacji wyjazdów, na czas od połowy lutego do świąt wielkanocnych, przed Wielkanocą zaś miało się odbyć kolejne spotkanie, na którym zamierzano ustalić harmonogram na okres po świętach i w razie potrzeby następne. Zgodnie z planem, na spotkaniu lutowym NCR miało wysłać PUPP zapotrzebowanie na pracowników, a te miały je podać do publicznej wiadomości wraz z miejscami rekrutacji. Na PUPP został także nałożony obowiązek powiadomienia pracowników, na których niemieccy pracodawcy złożyli imienne zapotrzebowanie oraz mieli zakontraktować ich do pracy. Wyboru robotników mieli dokonywać urzędnicy NCR w obecności urzędników PUPP. Po zakwalifikowaniu do podjęcia pracy robotnik podpisywał umowę skonstruowaną przez Fachową Komisję Rolną i Leśną przy Zakładzie Rzeszy dla Pośrednictwa Pracy i Ubezpieczenia Bezrobotnych (Fachausschussfür Land- und Forstwirtschaftbei der Reichsanstaltfür Arbeitsvermittlungund Arbeitslosenversicherung), po zapoznaniu się $\mathrm{z}$ nią $\mathrm{w}$ obecności pracownika PUPP. Czas po zakwalifikowaniu do wyjazdu nie powinien być, jak ustalono, dłuższy niż sześć tygodni. Pracownicy mieli otrzymać paszporty emigracyjne od władz polskich. Natomiast „Koszta transportu robotników od niemieckich stacji granicznych, oraz pieniądze na utrzymanie do miejsca pracy, o ile robotnicy nie zabrali ze sobą środków żywnościowych, ponosi pracodawca" ${ }^{\prime 65}$. Była to zatem pierwsza, obejmująca tak szerokie spektrum spraw umowa, zawarta między Polską a Niemcami, która w sposób korzystny dla polskich robotników sezonowych regulowała szereg kwestii, choć strona polska zgłaszała pewne niedociągnięcia ${ }^{66}$.

${ }^{65}$ Protokót rozszerzonego, prowizorycznego układu, zawartego na polsko-niemieckich rokowaniach w Berlinie 9 grudnia 1926 r. w sprawie polskiej emigracji sezonowej do Niemiec w roku 1927, „Przegląd Emigracyjny" 1926, z. 3/4. s. 148-154.

${ }^{66}$ Na przykład brak bezpośredniej opieki konsularnej nad pracownikami. Zob.: Posiedzenie Państwowej Rady Emigracyjnej z dnia 26 lutego 1927 r., „Przegląd Emigracyjny” 1927, z. 1, s. 29-30. 
W 1927 r. powiatowi wieluńskiemu przyznano tylko 16,5 tysięcy miejsc, podczas gdy do końca lutego zapisało się 38 tysięcy chętnych osób ${ }^{67}$, a wkrótce liczba ta powiększyła się do ok. 45 tysięcy robotników ${ }^{68}$. Ostatecznie Niemcy zwiększyli zapotrzebowanie na pracowników sezonowych dla powiatu wieluńskiego do 19 tysięcy osób ${ }^{69}$. W tymże roku z Polski do Niemiec wyjechało 69 tysięcy osób ${ }^{70}$.

Umowę z 9 grudnia 1926 r. zastąpiono 24 listopada 1927 r. traktatem emigracyjnym, który regulował całościowo kwestie emigracyjne robotników polskich. Niezwykle ważne z punktu widzenia polskich pracowników było zrównanie ich $\mathrm{z}$ niemieckimi $\mathrm{w}$ zakresie ochrony pracy, opieki społecznej, warunków pracy, postępowania rozjemczego, sądów pracy, prawa do organizowania się zawodowego i ustawodawstwa socjalnego ${ }^{71}$. Natomiast procedura rekrutacji była podobna jak w umowie z grudnia $1926 \mathrm{r}$. I tak w grudniu NCR miała zgłaszać przypuszczalne zapotrzebowanie na robotników w poszczególnych jednostkach administracyjnych w Niemczech oraz określała te powiaty w Polsce, z których chciałaby otrzymać pracowników. W ciągu kolejnych trzech tygodni UEW miał przekazać do wiadomości NCR informacje, z jakich powiatów i w jakiej liczbie pracowników przewiduje rekrutacje. W ciągu kolejnych dwóch tygodni MPiOS i NCR miało ustalać liczbę robotników, obszar rekrutacji i szczegóły techniczne. Następnie NCR miała wysyłać do PUPP informacje o zapotrzebowaniu na pracowników, terminy i miejsca rekrutacji, a te ogłaszać do publicznej wiadomości. Następnie w określonym miejscu i czasie mieli pojawić się urzędnicy NCR, którzy w porozumieniu z urzędnikami z PUPP mieli dokonywać rekrutacji do pracy w Niemczech. Wyboru na podstawie warunków fizycznych, kwalifikacji zawodowych i przy uwzględnieniu możliwości stworzenia $\mathrm{z}$ nich jednej grupy robotniczej mieli dokonywać wyłącznie niemieccy urzędnicy. Po przyjęciu do pracy robotnik podpisywał umowę sporządzoną przez Fachową Komisję Rolną i Leśną przy Zakładzie Rzeszy dla Pośrednictwa Pracy i Ubezpieczenia Bezrobotnych w obecności polskiego urzędnika. Następnie emigrant otrzymywał tzw. pasz-

${ }^{67}$ APŁOS, SPW, sygn. 228, k. 12 Sprawozdanie sytuacyjne SWi za luty 1927 r.

${ }^{68}$ Tamże, k. 31 Sprawozdanie sytuacyjne SWi za marzec 1927 r.

${ }^{69}$ Tamże, k. 34 Sprawozdanie tygodniowe SWi z dn. 3 V 1927 r. Zob. także: tamże, k. 37 Sprawozdanie tygodniowe nr 3 SWi z dn. 27 V 1927 r. Nie uwzględnia zwiększenia kontyngentu: W. Spaleniak, Emigracja sezonowa polskich robotników rolnych do Niemiec (1919-1939), Zamość 2010, s. 199.

${ }^{70}$ H. Janowska, Emigracja zarobkowa z Polski 1918-1939, Warszawa 1981, s. 175.

${ }^{71}$ Konwencja polsko-niemiecka $z$ dnia 24 listopada 1927 r. w sprawie polskich robotników rolnych, [w:] Prawo o emigracji w Polsce: teksty ustaw, rozporządzeń, instrukcyj oraz układów międzynarodowych wraz z komentarzem, oprac. S. Iwanowski, K. Mamrot, Warszawa 1929, s. 302-319; Porozumienie $w$ sprawie rekrutacji, pośredniczenia $i$ kontraktowania, jakoteż przejazdu polskich sezonowych robotników rolnych, [w:] tamże, s. 319-328; Z. Landau, J. Tomaszewski, Zarys historii gospodarczej Polski 1918-1939, Warszawa 1999, s. 174; W. Spaleniak, Prawno-polityczne..., s. 57-58. 
port emigracyjny sezonowy, upoważniający go do wyjazdu z Polski. W czasie rekrutacji powinien być także poinformowany o miejscu i terminie wyjazdu, przy czym koszty podróży od granicy do pracodawcy i koszty żywności, o ile nie miał swojej, pokrywał zatrudniający. Z kolei powrót powinien odbywać się w sposób uporządkowany, możliwie specjalnymi pociągami, a NCR miał zawiadamiać UEW o drogach, terminach i przejściach granicznych, do których zmierzali robotnicy. Inną grupę stanowili robotnicy, na których przychodziło imienne zapotrzebowanie z Niemiec, wówczas to polskie urzędy pośrednictwa pracy powinny jak najszybciej się z nimi skontaktować, gdy otrzymają na nich zapotrzebowanie i zakontraktować ich do pracy. Gdyby ci odmówili przyjęcia pracy w miejscach, gdzie zgłoszono na nich zapotrzebowanie, wówczas musieli przechodzić procedurę jak pozostali ${ }^{72}$.

W następnych latach nadeszły dla robotników ciężkie czasy. Zmniejszenie zapotrzebowania na ich pracę na zachód od Prosny spowodowało, że wielu z nich pozostawało bez zatrudnienia, a to wpływało na pogorszenie nastrojów społecznych. Wystarczy zaznaczyć, że 18 maja 1928 r. na Starym Rynku w Wieluniu zebrało się ok. pięciuset robotników sezonowych, którzy chcieli wedrzeć się do starostwa, żądając wysłania ich na roboty do Niemiec. Do zgromadzonych przemówił naczelnik kancelarii starostwa Franciszek Wiśniewski, który wyjaśnił protestującym, że kontyngent na rok 1928 został wyczerpany, ale starostwo dążyło do przyznania kolejnych miejsc. Po wysłuchaniu mówcy zebrani rozeszli się ${ }^{73}$.

Liczba chętnych do wyjazdu w powiecie wieluńskim była ogromna. W latach 1926-1928 PUPP zgłaszało się po 44-48 tysięcy robotników, natomiast w 1931 r. chętnych było aż 62,4 tysiące pracowników (!), a Niemcy zgłosiły zapotrzebowanie zaledwie na 8 tysięcy robotników z Wieluńskiego ${ }^{74}$. Liczba ta oznaczała, że zgłosił się prawie co trzeci mieszkaniec, wliczając w to dzieci i starców (ok. 29 proc.). Natomiast w poprzednich latach strona niemiecka zgłaszała zapotrzebowanie na: w 1928 r. - 21 000, a w 1929 - 23000 osób5.

${ }^{72}$ Konwencja w sprawie polskich robotników rolnych, podpisana w Warszawie dnia 24 listopada 1927 r. (zatwierdzona uchwałą Rady Ministrów z dnia 24 lutego 1928 r.), Dz.U. RP 1929, nr 44, poz. 366. Zob. także: Oświadczenie Rządowe z dnia 6 czerwca 1929 r. w sprawie wymiany dokumentów ratyfikacyjnych: 1. Konwencji między Rzeczapospolita Polska a Rzesza Niemiecka w sprawie polskich robotników rolnych, wraz z Protokółem końcowym, 2. Porozumienia w sprawie rekrutacji, pośredniczenia $i$ kontraktowania, jako też przejazdu polskich sezonowych robotników rolnych, 3. Porozumienia w sprawie polskich robotników rolnych, którzy przybyli do Niemiec przed 31 grudnia 1925 roku i tamże pozostali, podpisanych w Warszawie dnia 24 listopada 1927 roku. Dz.U. RP 1929, nr 44, poz. 367.

73 APŁOS, Powiatowa Komenda Policji Państwowej w Wieluniu (dalej: PKPP), sygn. 340, k. 12 Sprawozdanie tygodniowe z ruchu zawodowego, narodowościowego, politycznego i sytuacji ogólnej komendanta powiatowego PP [dalej: STRZNPSOKPPP] z dn. 23 V 1928 r.

74 J. Tomaszewski, Czynniki wptywające na migracje..., s. 154; Z. Landau, J. Tomaszewski, Wielki kryzys 1930-1935, Warszawa 1982, s. 12-13.

75 W. Spaleniak, Emigracja..., s. 199. 
Natomiast wyjeżdżających nie było tak dużo, jak w rekordowym roku 1926, choć powiat wieluński był przez cały czas największym eksporterem sezonowej siły roboczej w skali powiatowej w Polsce $^{76}$.

Tabela 2. Emigracja sezonowa z powiatu wieluńskiego na tle emigracji z województwa łódzkiego i Polski do Niemiec w latach 1927-1931

\begin{tabular}{|r|c|c|c|c|}
\hline Rok & Wieluńskie* & Wieluńskie** & $\begin{array}{c}\text { Eódzkie bez } \\
\text { Wieluńskiego** }\end{array}$ & Polska** $^{*}$ \\
\hline 1927 & b.d. & & & \\
1928 & 23152 & & 78644 & 325488 \\
1929 & 22006 & 88287 & & \\
1930 & 19724 & & & \\
1931 & 8216 & & 78644 & 325488 \\
\hline \multirow{2}{*}{ Razem } & 73098 & 88287 & & \\
\cline { 2 - 5 } & & \multicolumn{2}{|r|}{166931} & \\
\hline
\end{tabular}

Źródło:

* Dane za: W. Skowron, Kryzys i skutki emigracji sezonowej, Warszawa 1932, s. 23. Według innych danych, w 1928 r. - 23,6 tys. Zob.: Z. Landau, J. Tomaszewski, Wielki kryzys..., s. 12.

** Dane za: A. Zarychta, $d z$. cyt., tabela X.

\section{Czasy wielkiego kryzysu ekonomicznego i zakaz emigracji sezonowej 1932-1937}

Wielki kryzys gospodarczy i pogorszenie się sytuacji gospodarczej w Niemczech odbił się także na zmniejszeniu liczby wyjeżdżających do pracy, co było pochodną dążenia władz niemieckich do ochrony swojego rynku pra-

76 Przed 1930 r. utrwaliła się praktyka, że po dostaniu się do Niemiec pracodawca zgłaszał pracownika do konsulatu, a po stwierdzeniu obywatelstwa polskiego $\mathrm{w}$ starostwie wystawiano mu paszport. Takich przypadków, jak informował starosta, było do 4000 rocznie, natomiast po 1930 r. władze niemieckie zasadniczo nie przyjmowały robotników, którzy dostali się do pracy nielegalnie i liczba ta znacznie się zmniejszyła. Starosta wieluński wobec tego odnotowywał wzrost nielegalnych wyjazdów do Belgii. Zmieniła się także sytuacja z powrotami, przed $1929 \mathrm{r}$. bowiem robotnik wracający do kraju bez paszportu emigracyjnego po okazaniu innego dokumentu był wpuszczany do Polski. Natomiast po zaostrzeniu kontroli granicznej i nowej interpretacji artykułu 6. traktatu ryskiego, przekraczanie granicy przez robotników bez paszportu emigracyjnego od 1930 r. prawie nie występowało, także zmniejszyła się liczba robotników wracających przez zieloną granicę. Zob.: APŁ, UWŁ, sygn. 201, bp. Pismo SWi do WBP UWŁ z dn. 12 I 1931 r.; H. Janowska, Emigracja zarobkowa..., s. 175, 182; J. Tomaszewski, Czynniki wptywajace na migracje..., s. 144-145. Według liczby legitymacji wydawanych przez NCR, z Polski przyjechała w kolejnych latach następująca liczba robotników rolnych: 1928 - 116 904; 1929 - 103 540; 1930 - 77 708. Zob.: A. Jarzyna, dz. cyt., s. 92. 
cy przed napływem taniej siły roboczej z Polski. Taka postawa miała już miejsce w 1930 r., kiedy na posiedzeniu Komisji Rolnej Ministerstwa Rolnictwa Rzeszy, 22 października w Berlinie, na zadane pytanie, czy wobec olbrzymiego bezrobocia należy sprowadzać pracowników z Polski, wszyscy oprócz przedstawicieli z prowincji wschodnich odpowiedzieli, że nie. Wprowadzano z czasem kolejne ograniczenia na terenie Niemiec w przyjmowaniu robotników sezonowych, by ostatecznie 11 lutego 1932 r. Rada Rzeszy (Reichsrat) na wniosek Ministerstwa Pracy Rzeszy (Reichsarbeitsministerium) podjęła uchwałę o zamknięciu granicy dla robotników sezonowych; wypowiedziano konwencję emigracyjną i wprowadzono przymus opuszczenia Niemiec przez pracowników z Polski oprócz posiadających Befreiungsschein (zaświadczenie uprawniające do pobytu $)^{77}$. Tym samym granica została zamknięta i przez następne pięć lat nie było legalnych wyjazdów do pracy, a sytuacja na lokalnym rynku pracy była wręcz tragiczna. Część osób ratowała się nielegalnym wychodźstwem do pracy, co wiązało się z groźbą utraty życia przy przekraczaniu granicy $^{78}$.

Zamknięcie granicy i nakładający się na to kryzys gospodarczy spowodowały, że sytuacja była niezwykle trudna, a „Obecny kryzys, stale powiększająca się liczba bezrobotnych, zatrzymanie emigracji do Niemiec stały się żarem komunistów, którzy stan ten starają się wyzyskać dla swoich celów. Masy bezrobotnych namawia się do czynnych wystąpień przed urzędami państwowymi i domagania się żywności, ewentualnie pracy. Taka próba wystąpień miała miejsce w dniu 8. III. w Żytniowie". Tam bowiem przed lokalnym komitetem wiejskim pojawili się robotnicy, którzy próbowali usunąć jego członków, a posiadany przez instytucję chleb rozdzielić pomiędzy sobą $^{79}$. Dochodzacca do tego agitacja działaczy komunistycznych powodowała, że mieszkańcy w biały dzień organizowali napady na pociągi - zatrzymywali je i kradli z nich węgiel. Tylko w marcu 1932 r. dokonano dziewiętnaście wspomnianych aktów rabunkowych ${ }^{80}$. Sytuacja wraz z upływem czasu pogarszała się, tak że 10 kwietnia 1934 r. starosta nakazał „wystawić w godzi-

77 W. Spaleniak, Prawno-polityczne..., s. 58-60. Odnotować należy, że od początku $1931 \mathrm{r}$. władze niemieckie coraz częściej chciały przekazać Polsce osoby dla nich niewygodne, najczęściej matki z kilkorgiem dzieci, żyjących w nędzy, bez dokumentów, ponieważ mówiły po polsku. Starosta, jeżeli rzeczywiście stwierdził, że miały one obywatelstwo polskie, zgadzał się na ich wpuszczenie. Zob.: APŁ, UWŁ, sygn. 201, bp. Pismo SWi do WBP UWŁ z dn. 12 I 1931 r.

${ }^{78}$ Wśród gwizdów kul po pracę, "Głos Poranny" z 7 października 1932, nr 277, s. 3. Według oficjalnych statystyk, wyjechało do Niemiec: w 1932 r. - 0,4 tys. robotników; w 1933 - 0,7 tys.; w 1934 - 0,9 tys.; w 1935 - 1,0 tys.; w 1936 - 1,1 tys. Zob.: J. Tomaszewski, Czynniki wptywające na migracje..., s. 145.

${ }^{79}$ APŁOS, SPW, sygn. 712, k. 23 Sprawozdanie sytuacyjne nr 3 SWi za marzec 1932 r.

${ }^{80}$ Tamże, k. 27-28 Sprawozdanie sytuacyjne nr 3 SWi za marzec 1932 r. O takiej kradzieży węgla pisze sugestywnie Aleksander Pawelec, który pochodził z Lututowa, mieszkał przed II wojną światową w Małym Kacku i tam z biedy należał do gangu złodziei węgla. 
nach urzędowych stały posterunek policyjny przed gmachem Starostwa, którego zadaniem będzie niedopuszczenie do gromadzenia się grup bezrobotnych w Urzędzie Starostwa" ${ }^{11}$.

Dopiero zmiana sytuacji gospodarczej w III Rzeszy w związku z forsownymi zbrojeniami spowodowała, że wkrótce odczuto brak rąk do pracy zwłaszcza w rolnictwie, toteż władze niemieckie chciały podpisać kolejne porozumienie w sprawie robotników sezonowych na 1937 r., ale negocjacje w tej sprawie przeciągły się do czerwca ${ }^{82}$.

W tymże czasie obszary zachodnie kraju, a częściowo województwo warszawskie i białostockie, stały się obszarem nielegalnej rekrutacji „prowadzonej bezpośrednio lub pośrednio przez władze lub innego rodzaju instytucje niemieckie", a ponieważ taka sytuacja była szkodliwa z polskiego punktu widzenia, MSW zalecało m.in., by powracających do kraju na jesień karać tylko grzywnami finansowymi (maksymalnymi dla obywateli polskich narodowości niemieckiej, a dla Polaków stosować niższe), prowadzić rejestrację osób narodowości niemieckiej należących do organizacji hitlerowskich, a w przyszłości odmawiać „z reguły” wydawania przepustek i paszportów zagranicznych oraz umieszczać $\mathrm{w}$ lokalnej prasie artykuły przestrzegające ludność przed nielegalną emigracją ${ }^{83}$. W powiecie wieluńskim w lutym $1937 \mathrm{r}$. stwierdzono nielegalne wyjazdy do pracy oraz to, że część niemieckiej admi-

Zob.: A. Pawelec, Wspomnienia z lat młodości i II wojny światowej (1934-1945), Lututów-GdyniaPruszcz Gdański-Wieluń 2006, s. 17-19.

${ }^{81}$ APŁOS, SPW, sygn. 758, k. 2 Pismo SWi do posterunku Policji Państwowej w Wieluniu z 10 IV $1934 \mathrm{r}$.

${ }^{82}$ W. Spaleniak, Prawno-polityczne..., s. 61-62; E. Kołodziej, Wychodźstwo zarobkowe..., s. 227-228.

${ }^{83}$ APŁ, UWŁ, sygn. 207, bp. Pismo MSW do wojewodów i starostów z dn. 30 IX 1937 r. Niekorzystną zmianą, z punktu widzenia Polaków, były ograniczenia wywozu waluty niemieckiej z 10 do 3 marek, wprowadzone 15 stycznia 1937 r. w małym ruchu granicznych. We wrześniu część osób udawała się po pieniądze za pracę do Niemiec, ograniczenia zaś spowodowały, że niektórzy musieli nawet kilkanaście razy przekraczać granicę. Sytuacja ta związana była z manewrami wojskowymi na Śląsku oraz skuteczniejszą walką z wywozem nielegalnych pieniędzy za granicę. Niemiecka Straż Graniczna skuteczniej patrolowała granicę na rowerach, uzbrojona w kbk i pistolety, a napotkane osoby nielegalnie przekraczające granicę były dokładnie rewidowane. Według nowo wprowadzonej procedury, jeżeli osoba podczas rewizji nie zgłosiła, że miała więcej niż 3 marki, a celnicy znajdowali większą kwotę, była ona konfiskowana, ta osoba zaś musiała dostarczyć zaświadczenie od pracodawcy, że pieniądze te zostały zarobione legalnie. Po dostarczeniu zaświadczenia pieniądze były przesyłane do Banku Dewizowego w Berlinie, gdzie wymieniane były na złote polskie w stosunku 1:1 i przesyłane na wskazane konto do Polski lub do tego urzędu, gdzie zostały zarekwirowane. Gdy osoba nie mogła udowodnić, skąd ma pieniądze, wówczas kwotę ponad 3 marek przesyłano do sądu, gdzie następował jej przepadek. Zob.: APŁOS, SPW, sygn. 815, k. 20 Sprawozdanie sytuacyjne nr 1 SWi RWZB za styczeń 1937 r.; k. 205-206 Sprawozdanie sytuacyjne nr 9 SWi ze stanu bezpieczeństwa za wrzesień 1937 r.; k. 256 Sprawozdanie sytuacyjne nr 11 SWi ze stanu bezpieczeństwa za listopad $1937 \mathrm{r}$. 
nistracji tolerowała ten stan, a pracodawcy nielegalnych pracowników chętnie przyjmowali i ukrywali przed organami władzy ${ }^{84}$. Natomiast w kwietniu starosta wieluński alarmował, że znacznie wzrosło zapotrzebowanie na polskich robotników, toteż wielu dążyło do nielegalnego wyjazdu. Wzrosła także liczba wydawanych przepustek legalnych do przekroczenia granicy, a osoby te nie miały żadnych problemów ze znalezieniem pracy ${ }^{85}$. Duża emigracja nielegalna ustała pod koniec czerwca, co wiązało się z podpisaniem umowy polsko-niemieckiej, a władze niemieckie, choć nie do końca, przestały tolerować nielegalną emigrację zarobkową ${ }^{86}$. Według danych na 18 października 1937 r. nielegalnie do Niemiec wyjechało z powiatu wieluńskiego 2508 osób ${ }^{87}$. Wobec napiętej sytuacji politycznej władze polskie zakazywały konsulatom wydawania paszportów na pobyt za granicą i paszportów krótkoterminowych na powrót do kraju dla emigrantów nielegalnych, a ponieważ w takim wypadku robotnicy musieli wracać bez dokumentów, wszelkie wypadki miały być rejestrowanie i oddawane do sądu w celu pociągnięcia do odpowiedzialności karnej ${ }^{88}$.

\section{Przed wojną. Emigracja sezonowa w latach 1937-1939}

17 czerwca 1937 r. obie strony podpisały umowę, która ponownie przywróciła emigrację robotników sezonowych do Niemiec. Ustalono wówczas kontyngent na 10500 osób z siedemnastu powiatów, w tym dla 1500 robotników

${ }^{84}$ APŁOS, SPW, sygn. 815, k. 44 Sprawozdanie sytuacyjne SWi RWZB za luty 1937 r.

85 Tamże, k. 78 Sprawozdanie sytuacyjne nr 4 SWi ze stanu bezpieczeństwa za kwiecień 1937 r. Niemcy wydalili trzy grupy: 30 maja - 152 osoby, 31 maja - 34 osoby, 3 czerwca - 8 osób, ale były to osoby niezdolne do pracy lub z innych przyczyn niewygodne dla strony niemieckiej. Zob.: tamże, k. 102 Sprawozdanie sytuacyjne nr 5 SWi ze stanu bezpieczeństwa za maj 1937 r.

86 Tamże, k. 130-131 Sprawozdanie sytuacyjne nr 6 SWi ze stanu bezpieczeństwa za czerwiec $1937 \mathrm{r}$.

87 APŁ, UWŁ, sygn. 207, bp. Pismo SWi do Wydziału Społeczno-Politycznego [dalej: WS-P] UWŁ z dn. 18 X 1937 r. Emigracja nielegalna, według starosty, w 1937 r. miała następujące cechy: 1) robotnicy polscy byli cenieni w Niemczech, pracodawcy ukrywali ich pobyt, także władze prawdopodobnie ten stan tolerowały; 2) brak przestrzegania przepisów konwencji o małym ruchu granicznym - pobyt poza strefą $10 \mathrm{~km}$ od granicy nie napotykał trudności; 3) robotnicy byli wykorzystywani - gorsze warunki, mniejsze płace; 4) próby ominięcia opłat celnych dla zarobionej gotówki; 5) występowały przypadki, gdy robotnicy pracujący na przepustkach byli przywożeni przez Niemców na furmankach w niedzielę na granicę, by podstemplować przepustkę i wracali z powrotem do pracy; 6) robotnicy z byłego zaboru pruskiego byli lepiej cenieni i niektórych zatrudniano w fabrykach. Nielegalnie pracujący za dzień pracy (12 do 16 godzin) otrzymywał w 1937 r. od 1 do 2 marek, bez możliwości samowolnego opuszczenia stanowiska pracy, w przeciwnym razie skazywany był na miesiąc aresztu Zob.: tamże, bp. Pismo SWi do WS-P UWŁ z dn. 18 X 1937 r.; bp. Pismo starosty sieradzkiego do WS-P UWŁ z dn. 18 X 1937 r.

88 Tamże, bp. Pismo WS-P UWŁ do SWi z grudnia 1937 r. 
z Wieluńskiego. Oprócz możliwości legalnego przekraczania granicy władze niemieckie tolerowały nadal emigrację nielegalną, a niemiecki Arbeitsamt podpisywał umowy z osobami, które miały jakikolwiek dokument tożsamości ${ }^{89} .5$ lipca rozpoczął się nabór do pracy w Niemczech, lecz dla powiatu przyznano tylko 1500 miejsc, chociaż chętnych było kilka tysięcy ${ }^{90}$. W lipcu granicę polsko-niemiecką na odcinku wieluńskim przekroczyły 2844 osoby na podstawie dokumentów polskich oraz 168 niemieckich, a nielegalnie 139 osób. W lipcu czterema turami do Niemiec przeszło 1500 robotników polskich. Przejście ich obserwował 9 lipca prezydent Prowincji Śląskiej Karol Ordemann z wyższymi urzędnikami ${ }^{91}$. Późną jesienią rozpoczęły się powroty, a starosta mgr T. Niżankowski stwierdzał, że powrócili wszyscy robotnicy, zazwyczaj zadowoleni, z oszczędnościami w granicach od 200 do 400 marek $^{92}$, a „Dzisiaj przyjechali, ubrali się, majom co jeść i jakiś inny duch w tych ludzi wstąpił"93. Także sklepikarze w Praszce zaobserwowali wzrost sprzedaży i spłatę starych długów, toteż byli zwolennikami emigracji ${ }^{94}$. Łącznie z Polski wyjechało do III Rzeszy 12159 robotników ${ }^{95}$.

Konieczność wyjazdu do pracy była niecierpliwie oczekiwana przez samych zainteresowanych, a sołtys wsi Kowale w gminie Praszka stwierdzał po otwarciu granicy: „Bida tu, panie u tych ludzi była straszna. Jeść nie mieli co. Toteż jak tylko się ruszyło - wszystko to leciało na łeb na szyję, jakby ich jakoś gorączka ogarnęła. Przecie tu byli we wsi tacy, co już do gęby nie mieli co włożyć" ${ }^{\prime 96}$.

\footnotetext{
${ }^{89}$ W. Spaleniak, Prawno-polityczne..., s. 62; tegoż, Emigracja..., s. 199-200.

${ }^{90}$ APŁOS, SPW, sygn. 815, k. 130-131 Sprawozdanie sytuacyjne nr 6 SWi ze stanu bezpieczeństwa za czerwiec $1937 \mathrm{r}$.

${ }^{91}$ Tamże, k. 157-158 Sprawozdanie sytuacyjne nr 7 SWi ze stanu bezpieczeństwa za lipiec $1937 \mathrm{r}$.

92 Tamże, k. 294 Sprawozdanie sytuacyjne nr 12 SWi ze stanu bezpieczeństwa za grudzień 1937 r. W październiku rozpoczęły się pierwsze powroty robotników sezonowych. Często przewozili ze sobą drobne ilości różnego rodzaju towarów, jednakże władze celne umarzały przeciwko nim sprawy. Część robotników wracała w nienajlepszych humorach, skarżąc się na ciężką pracę, małe zarobki i kiepskie jedzenie; inni odwrotnie. Z kolei część pracodawców chciała zatrzymać polskich robotników na całą zimę, za mniejsze wynagrodzenie, jednakże robotnicy niezbyt chętnie wyrażali na to zgodę. Cześć pracodawców wypłacała także dodatkowe pieniądze przed wyjazdem i załatwiała odpowiednie formalności w kwestii wywozu pieniędzy. Zob.: tamże, k. 228-229 Sprawozdanie sytuacyjne nr 10 SWi ze stanu bezpieczeństwa za październik $1937 \mathrm{r}$.

${ }^{93}$ L. Landau, Wychodźstwo sezonowe na Łotwę $i$ do Niemiec w 1937 roku, Warszawa 1966, s. 144.

94 Tamże, s. 145.

${ }^{95}$ H. Janowska, Emigracja zarobkowa..., s. 195; A. Kicinger, Polityka emigracyjna II Rzeczpospolitej, Warszawa 2005, s. 19. Należy zauważyć, że władze niemieckie przy biernej postawie strony polskiej ściągnęły ok. 5-6 tysięcy robotników nielegalnych. Zob.: E. Kołodziej, Wychodźstwo zarobkowe..., s. 228.

${ }^{96}$ Cyt. za: L. Landau, dz. cyt., s. 143-144.
} 
Pod koniec 1937 r. zdecydowano, że w następnym roku do Niemiec wyjedzie maksymalnie 60 tysięcy robotników z 57 powiatów z Polski, w tym z Wieluńskiego - $11000^{97}$. Część robotników była gotowa przekroczyć nielegalnie granicę z powodu wysokich zarobków i pewności przyjęcia do pracy ${ }^{98}$. Natomiast w marcu 1938 r. granicę przekroczyło 600 robotników ${ }^{99}$, w kwietniu $4730^{100}$, w maju około $4000^{101}$, a w czerwcu $1021^{102}$, z całego kraju zaś ponad pięciokrotnie więcej niż w poprzednim roku, bo 63611 osób ${ }^{103}$. Mimo uruchomienia wyjazdów przyznany kontyngent był zbyt mały; w czerwcu bowiem przed lokalem gminy w Galewicach zebrało się około 150 osób, żądając wysłania ich na roboty rolne. Tłum chciał wedrzeć się do budynku gminy, wznoszono okrzyki przeciwko wójtowi, wobec czego zebranych rozpędziła policja, a siedmiu głównych sprawców ukarano czterodniowym aresztem ${ }^{104}$.

Ostatnia prowizoryczna umowa polsko-niemiecka została zawarta 3 lutego 1939 r. (oparta na przepisach z 1927 r.), w której ustalono, że do Niemiec uda się 90 tysięcy polskich robotników, w tym dla powiatu wieluńskiego przeznaczono 16000 miejsc, a więc w skali powiatowej, ponownie najwięcej w całej Polsce. Jednakże napięta sytuacja polityczna i zerwanie przez Niemcy deklaracji o niestosowaniu przemocy (28 kwietnia 1939 r.) spowodowały, że władze polskie ponownie zakazały wyjazdu robotników ${ }^{105}$. Trwały za to wyjaz-

97 Z. Landau, J. Tomaszewski, Lata interwencjonizmu państwowego 1936-1939, Warszawa 1989, s. 21; W. Spaleniak, Prawno-polityczne..., s. 62; tegoż, Emigracja..., s. 199-200.

98 APŁ, UWŁ, sygn. 2522k, k. 30 Sprawozdanie sytuacyjne WŁ ze stanu bezpieczeństwa, ruchu zawodowego i wywrotowego (dalej: SBRZW) za styczeń 1938 r.

99 Tamże, k. 96 Sprawozdanie sytuacyjne WŁ SBRZW za marzec 1938 r.

100 Tamże, k. 127 Sprawozdanie sytuacyjne WŁ SBRZW za kwiecień 1938 r.

101 Tamże, k. 158 Sprawozdanie sytuacyjne WŁ SBRZW za maj 1938 r.

102 Tamże, k. 188 Sprawozdanie sytuacyjne WŁ SBRZW za czerwiec 1938 r.

103 H. Janowska, Emigracja zarobkowa..., s. 195; A. Kicinger, dz. cyt., s. 19. Początkowo strona niemiecka chciała zatrudnić ok. 30 tysięcy robotników sezonowych, jednakże wobec słabego napływu z innych krajów (m.in. z Włoch) zwiększyła kontyngent do 60 tysięcy osób. Według danych niemieckich, było to 60786 robotników. Oprócz tego udało się do III Rzeszy około 15-20 tysięcy robotników nielegalnych. Zob.: E. Kołodziej, Wychodźstwo zarobkowe..., s. 228.

104 Sprawozdanie sytuacyjne wojewody tódzkiego ze stanu bezpieczeństwa, ruchu zawodowego i wywrotowego za czerwiec 1938 r., [w:] Sprawozdania wojewody tódzkiego: rok 1938. Czesść 2: stan bezpieczeństwa, ruch wywrotowy i zawodowy, red. naukowa J. Walicki, Łódź 2014, s. 213.

105 P. Łossowski, Położenie międzynarodowe i polityka zagraniczna, [w:] Polska Odrodzona 19181939: państwo - społeczeństwo - kultura, pod red. J. Tomickiego, Warszawa 1982, s. 196-197; A. Skrzypek, Wobliczu wojny (październik 1938-sierpień 1939), [w:] Historia dyplomacji polskiej, t. 4, pod red. P. Łossowskiego, Warszawa 1995, s. 594; M.J. Zacharias, Ku wojnie, [w:] M.K. Kamiński, M.J. Zacharias, Polityka zagraniczna Rzeczypospolitej Polskiej 1918-1939, Warszawa 1998, s. 255; W. Spaleniak, Prawno-polityczne..., s. 63; tegoż, Emigracja..., s. 199-200; J. Krasuski, PolskaNiemcy. Stosunki polityczne od zarania po czasy najnowsze, Wrocław 2009, s. 307; M. Wołos, Szkic o polskiej polityce zagranicznej w międzywojennym dwudziestoleciu, [w:] Dwudziestolecie, pod red. K. Persaka i P. Machcewicza, Warszawa 2009, s. 265. W grudniu 1938 r. rozpoczęły się polskoniemieckie negocjacje, w których Niemcy wykazywały zainteresowanie 60 tysiącami robotni- 
dy nielegalne, a do końca kwietnia 1939 r. wyjechało głównie z Wieluńskiego ok. 2000 osób. Mimo pierwszych pozytywnych wieści o zapotrzebowaniu na robotników, wkrótce zaczęły napływać informacje o ciężkich warunkach pracy, niskich zarobkach, o problemach z przesyłaniem pieniędzy do kraju, słabym wyżywieniu i kontrolowaniu oraz coraz liczniejszych pogłosek o zbliżającej się wojnie - w czerwcu 1939 r. emigracja nielegalna ustała ${ }^{106}$.

\section{Wokół emigracji sezonowej}

W okresie międzywojennym działał szereg różnych organizacji społecznych zajmujących się pomocą prawną i materialną emigrantom ${ }^{107}$, a od $1927 \mathrm{r}$. jedno z nich, czyli Polskie Towarzystwo Emigracyjne objęło opiekę nad emigrantami na granicy polsko-niemieckiej ${ }^{108}$.

Omawiając emigrację sezonową, nie sposób pominąć różnorakich nadużyć z jednej i drugiej strony, których ofiarą padali robotnicy sezonowi. Wśród nich można wskazać, że zimą 1925 i 1926 r. władze niemieckie starały się wydalić jak najwięcej robotników sezonowych, a także bezrobotnych i chorych będących ciężarem dla dobroczynności publicznej w Niemczech, a których narodowość nie mogła zostać jednoznacznie potwierdzona. Na teren Wieluńskiego w końcu stycznia 1926 r. próbowano przerzucić jedno chore na gruźlicę małżeństwo, które potrafiło mówić po polsku. Gdy polski po-

ków sezonowych oraz sugerowały zatrudnienie dla 150 tysięcy robotników przemysłowych. Później zwiększyły liczbę robotników rolnych do 90 tysięcy (negocjacje 20 stycznia - 3 lutego 1939 r.). Zob.: E. Kołodziej, Wychodźstwo zarobkowe..., s. 229-231. W lutym 1939 r. UWŁ otrzymał informację, że polscy robotnicy legalni i nielegalni nie będą zatrudniani na pograniczu, lecz w głębi kraju, a tutaj mieli być zatrudniani robotnicy z Sudetów. Zob.: Sprawozdanie sytuacyjne wojewody tódzkiego ze stanu bezpieczeństwa, ruchu zawodowego i wywrotowego za luty 1939 r., [w:] Sprawozdania wojewody tódzkiego: rok 1939. Część 2: stan bezpieczeństwa, ruch wywrotowy i zawodowy, red. naukowa J. Walicki, Łódź 2014, s. 59.

106 Sprawozdanie sytuacyjne wojewody łódzkiego ze stanu bezpieczeństwa, ruchu zawodowego i wywrotowego za kwiecień 1939 r., [w:] Sprawozdania wojewody tódzkiego: rok 1939. Część 2..., s. 127; Sprawozdanie sytuacyjne wojewody łódzkiego ze stanu bezpieczeństwa, ruchu zawodowego i wywrotowego za maj 1939 r., [w:] tamże, s. 163; Sprawozdanie sytuacyjne wojewody tódzkiego ze stanu bezpieczeństwa, ruchu zawodowego i wywrotowego za czerwiec 1939 r., tamże, s. 193.

$107 \mathrm{~J}$. Plewko, Instytucjonalne formy opieki nad emigracja z ziem polskich. Zarys problematyki, „Rocznik Nauk Społecznych” 2009, t. 1(37), s. 124-125, 129-130; A. Kicinger, dz. cyt., s. 35-39.

${ }^{108}$ Pomoc miała polegać na: „1) zorganizowanie kantyn, gdzie robotnicy będą otrzymywali pożywienie po cenie kosztów własnych, względnie bezpłatnie, jeżeli chodzi o robotników, nie posiadających środków na uiszczenie opłaty, 2) opieka moralna nad kobietami samotnemi, dziećmi i rodzinami, 3) współpraca z organami bezpieczeństwa w ochronie robotników przed wyzyskiem ze strony spekulantów, 4) dozór i zarząd emigracyjnymi domami noclegowymi". APŁOS, SPW, sygn. 172, k. 129 Pismo Urzędu Emigracyjnego w Warszawie do SWi z dn. 29 IX $1927 \mathrm{r}$. 
sterunek graniczny ich nie przyjął, Niemcy jeszcze dwukrotnie przerzucali ich nielegalnie przez zieloną granicę $e^{109}$.

Nie brakowało także incydentów po stronie polskiej. 30 kwietnia $1928 \mathrm{r}$. aresztowano w związku z nadużyciami przy wysyłaniu robotników za granice wójta gminy Starzenice Franciszka Parzyjagła ${ }^{110}$, a 7 maja tegoż roku aresztowano wójta gminy Galewice Adama Dusia oraz Marcina Dębskiego i Stanisława Szukałę - członków komisji werbunkowej, i Stanisława Kujawskiego - kancelarzystę tejże gminy ${ }^{111}$. Odnotowane nadużycia spowodowały, że komendant powiatowy policji w $1929 \mathrm{r}$. zwracał się do starostwa, aby te w nadchodzącym sezonie prowadziło ściślejszy nadzór nad wójtami i komitetami, które przydzielały przepustki do pracy w Niemczech, gdyż „wójtowie gmin i komitety uprawnione do wydawanie przepustek dokonywały nadużyć przez pobieranie opłat za przepustki od osób zamożnych, a tem samem nieuprawnionych do wyjazdu na roboty za granicę. Skutki powyższego były takie, że wiele osób zupełnie biednych nie mających środków utrzymania, pozostało w kraju, następstwem czego były niepożądane scysje i awantury urządzane przed gmachem Starostwa"112.

Oprócz legalnego przekraczania granicy, robotnicy sezonowi przechodzili granicę nielegalnie $\mathrm{w}$ obie strony $\mathrm{i}$ to nie tylko $\mathrm{w}$ okresie, gdy nie można było zgodnie z prawem tego robić. Otóż, mimo unormowań prawnych polskie władze w kwietniu 1926 r. stwierdzały, że nadal organizowany jest nielegalny przemyt ludzi - małymi grupkami. Emigranci mieli tłumaczyć się tym, że nie wiedzieli o bezpłatnych paszportach, przemytnicy zaś mieli to przed nimi zatajać, informując ich, że tylko drogą nielegalną mogą przekroczyć granicę. Jedną z takich grup miał przeprowadzać przez granicę mieszkaniec Częstochowy Wacław Konieczny. Władze wojewódzkie żądały solidnego ukarania go przez władze starostwa, gdyby udało się go złapać113. Także w 1938 r. działali tutaj nielegalni pośrednicy, którzy po pobraniu dużych opłat od robotników uciekli, zostawiającich samych na granicy ${ }^{114}$.

Powrót do kraju wiązał się z odprawą celną. Początkowo w Praszce nie było odpowiedniego miejsca, a „rewizja celna z braku odpowiedniego lokalu musi się odbywać przed komorą celną wprost na drodze, na powietrzu otwartem, i trwa kilka godzin dziennie narażając powracających na przebywanie na zimnie i słocie, co powoduje bardzo częste zachorowania, a wie-

\footnotetext{
109 APŁOS, SPW, sygn. 167, k. 1 Sprawozdanie sytuacyjne SWi za styczeń 1926 r.

110 APŁOS, PKPP, sygn. 340, k. 9 STRZNPSOKPPP z dn. 2 V 1928 r.

111 Tamże, k. 10 STRZNPSOKPPP z dn. 9 V $1928 \mathrm{r}$.

112 APŁOS, PKPP, sygn. 386, k. 9 STRZNPSOKPPP z dn. 6 II 1929 r.

113 APŁOS, SPW, sygn. 167, k. 112 Pismo z WS-P UWŁ do SWi z dn. 21 IV 1926 r.

${ }^{114}$ Nielegalni pośrednicy emigracyjni, „Echo” z 14 lutego 1938, nr 45, s. 4.
} 
lu wypadkach powoduje nawet śmierć"115. W związku z tym w drugiej połowie października $1926 \mathrm{r}$. Wydział Powiatowy podjął decyzję o budowie baraku na halę rewizyjną ${ }^{116}$. Prace przebiegły bardzo szybko, koszty opłacił Wydział, a już 4 grudnia 1926 r. starosta nakazał burmistrzowi Praszki Ignacemu Kowalczykowi przejęcie opieki nad wybudowanym budynkiem, przy czym utrzymać miał go nadal Wydział Powiatowy ${ }^{117}$. Koszt wyniósł $12112 z^{118}$.

Oprócz braku hali rewizyjnej nie było także odpowiedniej poczekalni dla powracających i czekających tu robotników. W 1926 r. kolejka z Praszki wyjeżdżała tylko raz dziennie do Wielunia o 13.00, natomiast odprawy celne trwały do 17.00 lub 18.00, a to powodowało, że robotnicy byli zmuszeni pozostawać na noc w Praszce, która nie mogła zapewnić odpowiedniej liczby miejsc noclegowych ${ }^{119}$. Starosta planował wybudować budynek parterowy o murze pruskim o wielkości 40x10x3,30 m za kwotę 25000 zł albo o wymiarach $24 \times 11 \times 8,50 \mathrm{~m}$ - piętrowy za kwotę 50000 zł. Ze względu na długi czas budowy i okres zimowy, który uniemożliwiał wzniesienie obiektu murowanego, starosta przystał na propozycję, aby przerobić istniejący spichlerz zbożowy należący do Adolfa Sudowicza (koszt do 3000 zł) ${ }^{120}$. Jednak ostatecznie starosta zaproponował dwa rozwiązania: $w$ pierwszym brano pod uwagę przebudowę istniejącego spichlerza zbożowego, która miała kosztować 4250 zl, a drugie polegało na wybudowaniu nowego lokalu za kwotę 10400 zł (30x10x3 m). Starosta opowiadał się za wariantem droższym, co wynikało z faktu, że tymczasowo barak miał lepiej odpowiadać robotnikom, łatwiej dało się wznieść konstrukcję drewnianą, a nabycie placu nie pociągało dużych kosztów, natomiast A. Sudowicz żądał dość wygórowanej ceny - 1000 dolarów - za sprzedaż swojego spichlerza (także żądał wygórowanej ceny za jego ewentualną dzierżawę). Poza tym była to już nieodpowiednia pora na przebudowę, aby zdążyć przed wiosennym ruchem emigracyjnym ${ }^{121}$.

${ }^{115}$ APŁOS, SPW, sygn. 172, k. 8 Pismo SWi do dyrektora Komory Celnej w Praszce z dn. $28 \times 1926 \mathrm{r}$.

116 Tamże, k. 91 Pismo SWi do WŁ z dn. 7 VI 1927 r.

117 Tamże, k. 24 Pismo SWi do burmistrza Praszki z dn. 4 XII 1926 r. Starosta zapowiadał, że budowa zakończy się do 30 listopada 1926 r. Zob.: tamże, k. 12 Pismo SWi do WŁ z dn. 24 XI $1926 \mathrm{r}$.

118 APŁ, UWŁ, sygn. 2765, k. 40 Wykaz inwestycji Wieluńskiego Powiatowego Związku Komunalnego.

${ }^{119}$ Sytuacja taka była w poniedziałki, środy, piątki i soboty, a w pozostałe dni o 8.15 i o 18.00, toteż starosta wnioskował, żeby uruchomić po dwa kursy pociągów od 10 listopada do 10 stycznia. Zob.: APŁOS, SPW, sygn. 172, k. 5 Pismo SWi do Wydziału Kolei Państwowych Wąskotorowych w Warszawie z dn. 25 X 1926 r.

120 Tamże, k. 39 Pismo SWi do WŁ z dn. 28 XII 1926 r.

${ }^{121}$ Tamże, k. 32 Pismo SWi do WBP UWŁ z dn. 13 I 1927 r. 
12 lutego 1927 r. UWŁ nakazał budowę nowego lokalu, a 14 marca przysłał na ten cel $12400 \mathrm{z}^{122}$. Wówczas „Wybudowano dom noclegowy w ryglówkę na fundamencie z pustaków cementowych. Ryglówka z obu stron obita szalówką z desek $1 \mathrm{cal}$, a od strony zewnętrznej spoiny desek zabite listewkami [...] długość $30 \mathrm{~m}$, szerokość $10 \mathrm{mtr}$. wysokość $2,80 \mathrm{~m}$. Budynek podzielono na dwie duże sale każda dług. $13 \mathrm{mtr}$. szer. 9,70 mtr. oraz pokoiku 5,00 mtr. dł. 4,00 mtr. szerokiego i korytarza dł. 5,00 szer. 4,00 mtr". Koszt budowy wyniósł 18 788,67 z1123. 8 września 1927 r. oba lokale zwiedzał minister pracy Stanisław Jurkiewicz, gdy wraz z dyrektorem Urzędu Emigracyjnego przyjechał do Wielunia, by zobaczyć jak wyglądają sprawy emigracji robotników, a następnie wraz ze starostą udał się do Praszki, po czym odjechał w kierunku Częstochowy ${ }^{124}$.

W 1935 r. Wydział Powiatowy zdecydował, do czego przychyliła się Rada Powiatowa, aby sprzedać dom noclegowy i halę rewizyjną związku z brakiem emigracji i reemigracji oraz koniecznością ponoszenia kosztów utrzymania budynków. Spodziewano się za nie otrzymać 3000 z $1^{125}$.

W związku z tym, że robotnicy polscy przywożeni byli do Zawisnej, następnie przechodzili $0,5 \mathrm{~km}$ do polskiej komory celnej, dalej wędrowali przez Praszkę na stację kolei, czyli łącznie nieco ponad $1 \mathrm{~km}$, a sama stacja była mała, o wymiarach zaledwie $15,65 \times 4,50 \mathrm{~m}$, trzech pokojach i z odkrytym peronem długości $60 \mathrm{~m}$ i $2 \mathrm{~m}$ szerokości, minister S. Jurkiewcz nakazał pobudować „bodaj najprymitywniejszy budynek na pomieszczenie Urzędu Celnego, posterunku policyjnego, sali rewizyjnej dla dopełnienia formalności celnych i poczekalni dla robotników, której obecnie przy stacji kolejki w Praszce zupełnie nie ma"126, a także wykonać dach nad peronem ${ }^{127}$. Działania takie były związane z przekonaniem, że kolejka niemiecka będzie przewozić robotników

122 Tamże, k. 92 Pismo SWi do WŁ z dn. 7 VI 1927 r. Odnotować należy, że początkowo sejmik przeznaczył na to $6000 \mathrm{zl}$, a następnie dołożył jeszcze 388,67zł, które później prawdopodobnie zostały przez UWŁ zwrócone. Zob.: tamże, k. 22 Pismo SWi do WŁ z dn. 27 XI 1926 r.; k. 96 Pismo SWi do WŁ z dn. 4 VI 1927 r.

${ }^{123}$ Tamże, k. 96 Pismo SWi do WŁ z dn. 4 VI 1927 r.; k. 97-98 Kosztorys wykonawczy z dn. 20 IV 1927 r.; APŁ, UWŁ, sygn. 2765, k. 40 Wykaz inwestycji Wieluńskiego Powiatowego Związku Komunalnego.

${ }^{124}$ APŁOS, SPW, sygn. 228, k. 63-64 Sprawozdanie tygodniowe nr 20 SWi z dn. 14 IX 1927 r.; Domy noclegowe dla obieżysasów na pograniczu polsko-niemieckim, "Łódzkie Echo Wieczorne” z 13 września 1927, nr 215, s. 2.

${ }^{125}$ Archiwum Akt Nowych w Warszawie, Związek Powiatów Rzeczypospolitej Polskiej w Warszawie, sygn. 499, k. 152 Protokół z I posiedzenia Wieluńskiej Rady Powiatowej z dn. 5 III $1935 \mathrm{r}$.

${ }^{126}$ APŁOS, SPW, sygn. 172, k. 117 Protokół Komisji z dn. 13 IX 1927 r.

127 „Barak stanąć ma na gruncie nienależącym do koleji, a z tyłu stacyjki i tuż obok niej na gruncie, który z rozporządzenia Pana Ministra Pracy i Opieki Społecznej został wydzierżawiony długoterminową dzierżawą. Kryty peron ma stanąć na froncie tego baraku, stanowiąc $\mathrm{z}$ barakiem jedną całość i wybudowany być może na gruncie należącym do kolejki. Poczekalnia 
do stacji w Praszce ${ }^{128}$. Do działań przystąpiono niezwłocznie. Już 14 września 1927 r. w Wieluniu zawarto umowę dzierżawy z Józefem Kamosińskim na działkę położoną bezpośrednio przy budynku stacji kolejowej ${ }^{129}$. Planowany koszt budowy wynosił $19530,57 \mathrm{z}^{130}$, a budowa została zakończona pod koniec listopada $1927 \mathrm{r}^{131}$

Powrót do kraju wiązał się także z koniecznością wymiany zarobionych pieniędzy. W pierwszych latach po wojnie na powracających Polaków czekali w Praszce i okolicznych wsiach handlarze waluty, przeważnie Żydzi. Była to ryzykowana operacja, robotnicy bowiem byli oszukiwani, gdyż nie znali bieżącego kursu walutowego. W 1925 r. pośrednicy wprowadzili sporo fałszywych pieniędzy, a poszkodowani tym procederem $\mathrm{w}$ obawie przed problemami na policji nie zgłaszali oszustw ${ }^{132}$. Takim wędrownym pośrednikiem, przemierzającym wsie w poszukiwaniu kontrahentów chcących dokonać wymiany waluty, był Żyd z Bolesławca, Abram Kon, zajmujący się początkowo handlem domokrążnym, który następnie zmienił profesję. Działalność ta zakończyła się dla niego tragicznie, gdyż został 15 grudnia 1927 r. zamordowany w okolicach Bolesławca ${ }^{133}$.

W związku z występującymi oszustwami starosta zaproponował, aby utworzyć w Praszce punkt wymiany waluty Banku Polskiego Oddział w Częstochowie. Przeprowadzono specjalną akcję informacyjną, a punkt został umieszczony w magistracie praszkowskim i rozpoczął działalność 16 listopada 1926 r., a następnego dnia zaczęto wymieniać banknoty, na odpowiedzialność starosty zaś także bilon (od 22 listopada). W pierwszym dniu wymieniono już 8143, a w drugim 2240 marek niemieckich ${ }^{134}$. Uruchomienie

ma stanąć obok istniejącej poczekalni również na gruncie do kolejki należącym”, tamże, k. 123 Pismo SWi do dyrekcji Kolei Państwowych Wąskotorowych w Warszawie z dn. 28 IX 1927 r.

${ }^{128}$ Niemcy mimo próśb zwlekali z przyjęciem polskich propozycji. Najpierw tłumaczono się, że most na Prośnie był zbyt słaby na transport ludzi, mimo że przewożono nim towary, a potem ostatecznie stwierdzono, że nie będzie na to zgody ze strony niemieckiej policji kryminalnej. Zob.: tamże, k. 144 Pismo SWi do landrata Rosenberga z dn. 14 XI 1927 r.; k. 65 Pismo SWi do MPiOS z dn. 26 XI $1927 \mathrm{r}$.

${ }^{129}$ Tamże, k. 116 Umowa z dn. 14 IX 1927 r.

130 Tamże, k. 123 Pismo SWi do dyrekcji Kolei Państwowych Wąskotorowych w Warszawie z dn. 28 IX 1927 r.; k. 121 Pismo z Urzędu Emigracyjnego w Warszawie do SWi z dn. 20 IX $1927 \mathrm{r}$.

131 Tamże, k. 65 Pismo SWi do MPiOS z dn. 26 XI 1927 r.

132 Tamże, k. 2 Pismo SWi do dyrektora Oddziału Banku Polskiego w Praszce z dn. 23 X 1926 r.; k. 8 Pismo SWi do dyrektora Komory Celnej w Praszce z dn. 28 X 1926 r.

${ }^{133}$ APŁOS, SPW, sygn. 228, k. 88 Sprawozdanie sytuacyjne nr 34 SWi z dn. 21 XII 1927 r.

${ }^{134}$ Wynikało to $\mathrm{z}$ faktu, że prywatni pośrednicy wymieniali także bilion, a robotnicy, nie mogąc w punkcie wymienić monet, udawali się do nich. Zob.: APŁOS, SPW, sygn. 172, k. 12 Pismo SWi do WŁ z dn. 24 XI 1926 r.; k. 11 Pismo SWi do Konsulatu Polskiego w Berlinie i Wrocławiu z dn. 29 X 1926 r. Od 27 listopada do 23 grudnia wymieniono: 803 601,40 marek niemieckich, 44695 franków francuskich, 10 funtów szterlingów, 425 dolarów amerykańskich, 
takiego punktu nie podobało się pewnym grupom ludności, które blokowały dostęp emigrantom do punktu, także musiała interweniować policja ${ }^{135}$. Zapewne i w następnych latach, a na pewno w 1927 r., uruchamiano taki punkt $^{136}$.

Zjawisko emigracji sezonowej do Niemiec niosło za sobą zarówno pozytywne, jak i negatywne skutki.

Wobec poważnych problemów natury materialnej, z jakimi borykała się miejscowa ludność, wyjazdy dawały możliwość przede wszystkim zdobycia pracy i zarobku oraz pewne poszerzanie horyzontów intelektualnych. Także miejscowi, którzy pozostawali na miejscu, czerpali z tego korzyści, emigranci bowiem zarobione (zaoszczędzone) pieniądze wydawali na miejscu u chłopów, rzemieślników i w innych działach gospodarki ${ }^{137}$. Ocenia się, że robotnicy przywieźli do Wieluńskiego: w 1927 r. - 10-12 mln zł; w 1928 13-15 mln zł; w 1929 - 14-17 mln zł; w 1930 - 12,5-15 mln zł, czyli były to znaczne ilości pieniądza ${ }^{138}$. Tym samym „, [...] po powrocie do domu (w jesieni) każdy taki robotnik czy robotnica przynosi ze sobą kilkaset zarobionych złotych, za które przeżyć może całą zimę i jako tako przyodziać się. Stokroć gorzej jest tym, którzy wyjechać nie mogą - zmarnuje bowiem drogi czas i nic zarobić nie może"139.

Nie brakowało także negatywnych efektów, gdyż „,[...] emigracja zgubnie działała na wynarodowienie wyjeżdżających, zwłaszcza nie uformowanej narodowo i nie wyrobionej życiowo młodzieży, pozbawionej opieki rodziców również źle wpływała pod względem moralnym. A w kraju gospodarstwa pozostawione słabym fizycznie dziadkom podupadały, a i dzieci

806 franków belgijskich, 45 franków szwajcarskich, 45 koron duńskich i 145 rubli. Zob.: tamże, k. 36 Wykaz wymienionych walut w Banku Polskim Oddział w Częstochowie w Praszce. W 1927 r. Bank także wymieniał walutę. Zob.: tamże, k. 145 Pismo z Oddziału Banku Polskiego w Częstochowie do SWi z dn. 2 XI 1927 r.; APŁOS, SPW, sygn. 228, k. 79 Sprawozdanie tygodniowe nr 30 SWi z dn. 23 XI 1927 r.

135 APŁOS, SPW, sygn. 172, k. 91 Pismo SWi do WŁ z dn. 7 VI 1927 r.

136 Troska państwa polskiego o wychodźców sezonowych, "Górnoślązak” z 29 grudnia 1929, nr 300, s. 1.

${ }^{137}$ Kwoty wpływów całkowitych dostarczanych przez emigrantów, Zob.: Z. Landau, J. Tomaszewski, Bank Polska Kasa Opieki S.A. 1929-1979, Warszawa 1983, s. 9.

${ }^{138}$ W. Skowron, Emigracja sezonowa do Niemiec jako zagadnienie społeczne i gospodarcze, Warszawa 1931, s. 16. Według obliczeń polskiego konsulatu w Szczecinie, w latach 1928-1929 średni zarobek polskich robotników w Niemczech wyniósł na jedną osobę od 300 do 500 marek niemieckich (600-1000 zł), co było poważną kwotą. Zob.: W. Skóra, Konsulat Rzeczypospolitej Polskiej w Szczecinie w latach 1925-1939. Powstanie i działalność, Słupsk 2001, s. 84-85. Natomiast Wincenty Chmyzowski, ziemianin ze Strojca, oceniał, że kobiety przywoziły 500 zł, a mężczyźni jeszcze więcej. Zob.: APŁ, UWŁ, sygn. 2559, k. 288 Dyskusja nad referatem starosty A. Choczyńskiego o bezrobociu i emigracji sezonowej w powiecie wieluńskim wygłoszonym na konferencji o potrzebach kulturalnych i gospodarczych powiatu wieluńskiego z dn. 4 II $1939 \mathrm{r}$.

139 A. Stasiak, Bolaczki zapadłej prowincji, „Hasło Łódzkie” z 17 lutego 1928, nr 48, s. 6. 
emigrantów pozbawione ojcowskiej ręki cierpiały pod względem nauki i wychowania. I co ciekawe ci bardzo dobrzy robotnicy, powróciwszy do swoich gospodarstw stosunkowo bardzo mało stosowali zdobycze niemieckiej kultury rolnej. Sądzę, gdyby pracowali u średniorolnych bauerów łatwiej byłoby podpatrzeć sposób ich gospodarowania, natomiast w wielkim gospodarstwie trudno było objąć całość, jedynie powierzony robotnikowi wąski dział $[\ldots]^{\prime \prime 140}$.

Inne kierunki emigracji zarówno sezonowej, jak i stałej były dla mieszkańców powiatu wieluńskiego mało atrakcyjne. Tak więc łącznie w okresie międzywojennym (1918-1938) z Polski wyjechało do Francji 607 tys. osób, czyli 29,7 proc. emigrantów i było to państwo najczęściej wybierane ${ }^{141}$, to $\mathrm{z}$ tego obszaru w latach 1926-1929, 1932-1938 wyjechało 1918 osób ${ }^{142}$. Kolejnym najczęściej wybieranym kierunkiem były Niemcy, a następnie USA, gdzie wyjechało na emigrację stałą 273,5 tysiąca osób ${ }^{143}$, podczas gdy z Wieluńskiego postanowiło wyjechać 32 osoby, z czego połowa była Żydami ${ }^{144}$.

\section{Zakończenie}

Emigracja sezonowa do Niemiec była charakterystycznym zjawiskiem dla powiatu wieluńskiego, skąd corocznie przez cały okres międzywojenny mniejsza lub większa liczba mieszkańców wyjeżdżała (legalnie i nielegalnie) do pracy, głównie w rolnictwie. Stąd też pochodziła największa grupa w skali powiatowej w Polsce, sięgając rekordowej liczby ok. 48 tys. osób (1926), przy czym najwięcej chętnych było w 1931 r., gdy taką deklarację złożyły 62 tysiące osób. Możliwość wyjazdów do pracy w największym stopniu zależała od polityki niemieckiej, która z wyjątkami (szczególnie wielki kryzys gospodarczy) z chęcią widziała polskich robotników, przekraczających granicę w sposób legalny i nielegalny. Także strona niemiecka decydowała o liczbie legalnie wyjeżdżających, która była zawsze mniejsza niż liczba chętnych. Trudna sytuacja gospodarcza w Polsce, zwłaszcza w rolnictwie, przekładająca się bezi dziś.

${ }^{140}$ MZW, ZS, nr 114/sp.in, k. 2, W. Zarzycki, Kótko rolnicze w Białej k. Wielunia - dawniej

${ }^{141}$ H. Janowska, Emigracja zarobkowa..., s. 203.

142 J. Milczarek, dz. cyt., s. 27. Dane przywołane przez autora mogą nieco odbiegać od rzeczywistości, starosta bowiem we wrześniu 1932 r. informował, iż PUPP zwerbował do pracy we Francji 302 kobiety, 17 mężczyzn i 2 rodziny, a wyjazd nastąpil, więc liczba osób, które wyjechały do nad Sekwanę, byłaby nieco większa, ale to i tak nie zmienia ogólnego obrazu. Dodatkowo w listopadzie zrekrutowano 45 kobiet, ale nie wiadomo, czy wyjazd się odbył. Zob.: APŁOS, SPW, sygn. 712, k. 126 Sprawozdanie sytuacyjne SWi RWZB za październik 1932 r.; k. 136 Sprawozdanie sytuacyjne SWi RWZB za listopad 1932 r.

${ }^{143}$ H. Janowska, Emigracja z Polski..., s. 367.

${ }^{144}$ J. Milczarek, dz. cyt., s. 27. 
pośrednio na rolniczy powiat wieluński powodowała, że emigracja sezonowa była najszybszym i najskuteczniejszym sposobem zatrudnienia bezrobotnych i łagodzenia napięć społecznych na tym terenie.

\section{Bibliografia}

\section{Źródła archiwalne}

Archiwum Akt Nowych w Warszawie

Związek Powiatów Rzeczypospolitej Polskiej w Warszawie, sygn. 499.

Archiwum Państwowe w Łodzi

Akta miasta Łodzi, sygn. 23670.

Urząd Wojewódzki Łódzki, sygn. 201, 207, 2522k, 2559, 2645, 2704a, 2765.

Archiwum Państwowe w Łodzi Oddział w Sieradzu

Powiatowa Komenda Policji Państwowej w Wieluniu, sygn. 340, 386.

Starostwo Powiatowe Wieluńskie, sygn. 69, 70, 99a, 167, 172, 228, 235, 712, 758, 767, 788, 815, 861, 2807.

Muzeum Ziemi Wieluńskiej

Zbiory Specjalne, nr 114/sp.in, k. 5. W. Zarzycki, Kótko rolnicze w Białej k. Wielunia - dawniej $i$ dziś.

\section{Źródła drukowane}

Dekret o samorzadzie miejskim, [w:] R. Szwed, Samorzad terytorialny w Polsce w latach 1918-1939. Wybór materiałów źródłowych, Częstochowa 2010.

Dziennik Praw Państwa Polskiego 1919.

Dziennik Urzędowy Komisarza Rządu Polskiego na Powiat Wieluński 1919.

Dziennik Ustaw Rzeczypospolitej Polskiej 1929.

Konwencja polsko-niemiecka $z$ dnia 24 listopada 1927 r. w sprawie polskich robotników rolnych, [w:] Prawo o emigracji w Polsce: teksty ustaw, rozporzadzeń, instrukcyj oraz układów międzynarodowych wraz z komentarzem, oprac. S. Iwanowski, K. Mamrot, Warszawa 1929.

Porozumienie w sprawie rekrutacji, pośredniczenia i kontraktowania, jakoteż przejazdu polskich sezonowych robotników rolnych, [w:] Prawo o emigracji w Polsce: teksty ustaw, rozporzadzen, instrukcyj oraz układów międzynarodowych wraz z komentarzem, oprac. S. Iwanowski, K. Mamrot, Warszawa 1929.

Sprawozdanie sytuacyjne wojewody łódzkiego ze stanu bezpieczeństwa, ruchu zawodowego i wywrotowego za czerwiec 1938 r., [w:] Sprawozdania wojewody tódzkiego: rok 1938. Część 2: stan bezpieczeństwa, ruch wywrotowy i zawodowy, red. naukowy J. Walicki, Łódź 2014.

Sprawozdanie sytuacyjne wojewody łódzkiego ze stanu bezpieczeństwa, ruchu zawodowego i wywrotowego za luty 1939 r., [w:] Sprawozdania wojewody tódzkiego: rok 1939. Część 2: stan bezpieczeństwa, ruch wywrotowy i zawodowy, red. naukowy J. Walicki, Łódź 2014.

Sprawozdanie sytuacyjne wojewody tódzkiego ze stanu bezpieczeństwa, ruchu zawodowego i wywrotowego za kwiecień 1939 r., [w:] Sprawozdania wojewody tódzkiego: rok 1939. Część 2: stan bezpieczeństwa, ruch wywrotowy i zawodowy, red. naukowy J. Walicki, Łódź 2014.

Sprawozdanie sytuacyjne wojewody tódzkiego ze stanu bezpieczeństwa, ruchu zawodowego i wywrotowego za maj 1939 r., [w:] Sprawozdania wojewody tódzkiego: rok 1939. Część 2: stan bezpieczeństwa, ruch wywrotowy i zawodowy, red. naukowy J. Walicki, Łódź 2014.

Sprawozdanie sytuacyjne wojewody łódzkiego ze stanu bezpieczeństwa, ruchu zawodowego i wywrotowego za czerwiec 1939 r., [w:] Sprawozdania wojewody tódzkiego: rok 1939. Część 2: stan bezpieczeństwa, ruch wywrotowy i zawodowy, red. naukowy J. Walicki, Łódź 2014. 


\section{Źródła statystyczne}

Drugi powszechny spis ludności z dn. 9. XII 1931 r. Mieszkania i gospodarstwa domowe. Ludność. Stosunki zawodowe. Województwo łódzkie bez miasta Łodzi, Warszawa 1938.

Pierwszy powszechny spis Rzeczypospolitej Polskiej z dnia 30 września 1921 roku. Gospodarstwa wiejskie: województwa centralne, Warszawa 1928.

Pierwszy powszechny spis Rzeczypospolitej Polskiej z dnia 30 września 1921 roku. Mieszkania. Ludność. Stosunki zawodowe. Województwo tódzkie, Warszawa 1928.

Rocznik statystyki Rzeczypospolitej Polskiej 1920/21, r. 1, cz.1, Warszawa 1921.

Rocznik Statystyki Rzeczypospolitej Polskiej 1925/1926, r. 4, Warszawa 1927.

Skorowidz gmin Rzeczypospolitej Polskiej. Ludność i budynki na podstawie tymczasowych wyników drugiego powszechnego spisu ludności z dn. 9 XII 1931 r. oraz powierzchnia ogólna i użytki rolne. Część I. Województwa centralne i wschodnie, Warszawa 1933.

Skorowidz miejscowości Rzeczypospolitej Polskiej opracowany na podstawie wyników pierwszego powszechnego spisu ludności z dn. 30 września 1921 r. i innych źródet urzędowych. T. II: województwo tódzkie, Warszawa 1925.

Statystyka Rolnicza 1930/1931, „Statystyka Polski”, Serja B, z. 1, Warszawa 1932.

\section{Prasa}

Domy noclegowe dla obieżysasów na pograniczu polsko-niemieckim, "Łódzkie Echo Wieczorne” z 13 września 1927, nr 215.

Komunikat z dn. 23 grudnia 1926 r. w sprawie emigracji do Niemiec, „Przegląd Emigracyjny” 1926, z. $3 / 4$.

Krasocki M., Ruch emigracyjny z Polski w I-em pótroczu 1926 r., „Przegląd Emigracyjny” 1926, $\mathrm{nr} 1$.

Nadzwyczajne posiedzenie Państwowej Rady Emigracyjnej z dnia 1 września 1926 r., „Przegląd Emigracyjny" 1926, z. 3/4.

Nielegalni pośrednicy emigracyjni, „Echo” z 14 lutego 1938, nr 45.

Nowa kolej na Górny Śląsk, "Głos Ziemi Wieluńskiej” z 21 marca 1926, nr 12.

Posiedzenie Państwowej Rady Emigracyjnej z dnia 26 lutego 1927 r., „Przegląd Emigracyjny” 1927, z. 1.

Protokót rozszerzonego, prowizorycznego układu, zawartego na polsko-niemieckich rokowaniach w Berlinie 9 grudnia 1926 r. w sprawie polskiej emigracji sezonowej do Niemiec w roku 1927, „Przegląd Emigracyjny" 1926, z. 3/4.

Rojewski L., Z Wieruszowa. Emigracja młodzieży, „Wielunianin” z 8 marca 1925, nr 10.

Ruch emigracyjny z Polski w 1926 r., "Przegląd Emigracyjny” 1927, z. 1.

Ruch migracyjny, warunki pracy i produkcji w obcych krajach, "Biuletyn Urzędu Emigracyjnego" 1925, nr 9-11.

Ruch reemigracyjny do Polski w 1926 r., „Przegląd Emigracyjny” 1927, z. 1.

Sprawy emigracyjne na sejmowej rozprawie budżetowej, „Przegląd Emigracyjny” 1927, z. 1.

Stasiak A., Bolaczki zapadłej prowincji, „Hasło Łódzkie” z 17 lutego 1928, nr 48.

Troska państwa polskiego o wychodźców sezonowych, "Górnoślązak” z 29 grudnia 1929, nr 300.

Uwagi do tablic, „Przegląd Emigracyjny” 1927, z. 1.

W sprawie wychodźstwa robotników sezonowych do Niemiec, „Głos Ziemi Wieluńskiej” z 14 lutego 1926, nr 7.

Wśród gwizdów kul po prace, „Głos Poranny” z 7 października 1932, nr 277.

\section{Wspomnienia}

Pawelec A., Wspomnienia z lat młodości i II wojny światowej (1934-1945), Lututów-Gdynia-Pruszcz Gdański-Wieluń 2006. 


\section{Mapy}

Województwa centralne i wschodnie Rzeczypospolitej Wschodniej. Podziat na gminy wedtug stanu z dnia 1. IV 1933 roku.

Mapa gmin Rzeczypospolitej Polskiej. Podziat administracyjny wedtug stanu z dnia 1. IV 1938 roku.

\section{Kalendarze}

Kalendarz Informator na Województwo Łódzkie na rok 1922, Łódź [1922].

Kalendarz Skarbowy na rok 1928.

\section{Opracowania}

Bandurka M., Zmiany administracyjne i terytorialne ziem województwa tódzkiego w XIX i XX wieku, Łódź 1995.

Borawski S., Rolnictwo w powiecie wieluńskim. Dane statystyczne i uwagi krytyczne, "Głos Polski” z 23 lipca 1929.

Chwalba A., Historia Polski 1795-1918, Kraków 2000.

Drozdowski M., Polityka gospodarcza rzadu polskiego 1936-1939, Warszawa 1963.

Drozdowski M.M., Życie gospodarcze Polski w latach 1918-1939, [w:] Z dziejów Drugiej Rzeczypospolitej, pod red. A. Garlickiego, Warszawa 1986.

Dudek A., Republika Weimarska - kryzys i stabilizacja, [w:] Historia polityczna świata XX wieku 19011945, pod red. M. Bankowicza, Kraków 2004.

Fiedor K., Władze niemieckie wobec polskich robotników rolnych w latach 1918-1932, „Śląski Kwartalnik Historyczny Sobótka" 1962, r. XVII, nr 2.

Groniowski K., Emigracja, [w:] Encyklopedia historii gospodarczej Polski do 1945 roku, A*N, Warszawa 1981.

Groniowski K., Emigracja z ziem zaboru rosyjskiego (1864-1918), [w:] Emigracja z ziem polskich w czasach nowożytnych i najnowszych (XVIII-XX w.), pod red. A. Pilcha, Warszawa 1984.

Janowska H., Emigracja z Polski w latach 1918-1939, [w:] Emigracja z ziem polskich w czasach nowożytnych i najnowszych (XVIII-XX w.), pod red. A. Pilcha, Warszawa 1984.

Janowska H., Emigracja zarobkowa z Polski 1918-1939, Warszawa 1981.

Jarzyna A., Polityka emigracyjna, Lwów 1933.

Jędruszczak H., Płace robotników przemystowych w Polsce w latach 1924-1939, Warszawa 1963.

Kicinger A., Polityka emigracyjna II Rzeczpospolitej, Warszawa 2005.

Kołodziej E., Gospodarka wojenna w Królestwie Polskim w latach 1914-1918, Warszawa 2018.

Kołodziej E., Wychodźstwo zarobkowe z Polski 1918-1939: studia nad polityka emigracyjna II Rzeczypospolitej, Warszawa 1982.

Kozłowski J., Emigracja okresu schyłkowego Rzeczypospolitej szlacheckiej i porozbiorowa (do 1864 r.), [w:] Emigracja z ziem polskich w czasach nowożytnych i najnowszych (XVIII-XX w.), pod red. A. Pilcha, Warszawa 1984.

Krasuski J., Polska - Niemcy. Stosunki polityczne od zarania po czasy najnowsze, Wrocław 2009.

Książek J., Pierwsza wojna światowa (1914-1918), [w:] Monografia gminy Wierzchlas, pod red. Z. Włodarczyka, Wierzchlas 2014.

Książek J., Powiat wieluński w latach 1918-1939, „Rocznik Wieluński” 2001, t. I.

Książek J., Życie społeczno-polityczne i gospodarcze Lututowa w latach 1914-1939, [w:] Sześć wieków Lututowa. Studia i materiaty, pod red. T. Olejnika, Wieluń 2007.

Kulczycki L., Prowizoryczna umowa polsko-niemiecka w sprawie emigracji, „Przegląd Polityczny” 1927, z. 3/4.

Landau L., Wychodźstwo sezonowe na Łotwę i do Niemiec w 1937 roku, Warszawa 1966.

Landau L., Pański J., Strzelecki E., Bezrobocie wśród chłopów, Warszawa 1939.

Landau Z., Bezrobocie, [w:] Encyklopedia historii gospodarczej Polski do 1945 r.: A-N, red. naczelny A. Mączak, Warszawa 1981. 
Landau Z., Gospodarka polska w latach 1918-1939, [w:] B. Zientara, A. Mączak, I. Ihnatowicz, Z. Landau, Dzieje gospodarcze Polski do 1939 r., Warszawa 1965.

Landau Z., Tomaszewski J., Bank Polska Kasa Opieki S.A. 1929-1979, Warszawa 1983.

Landau Z., Tomaszewski J., Gospodarka Drugiej Rzeczypospolitej, Warszawa 1991.

Landau Z., Tomaszewski J., Lata interwencjonizmu państwowego 1936-1939, Warszawa 1989.

Landau Z., Tomaszewski J., Od Grabskiego do Pitsudskiego. Okres kryzysu poinflacyjnego i ożywienia koniunktury 1924-1929, Warszawa 1971.

Landau Z., Tomaszewski J., Trudna niepodległość. Rozważania o gospodarce Polski 1918-1939, Warszawa 1978.

Landau Z., Tomaszewski J., W dobie inflacji 1918-1923, Warszawa 1967.

Landau Z., Tomaszewski J., Wielki kryzys 1930-1935, Warszawa 1982.

Landau Z., Tomaszewski J., Zarys historii gospodarczej Polski 1918-1939, Warszawa 1999.

Lewandowski J., Okupacja austriacka w Królestwie Polskim (1914-1918), „Dzieje Najnowsze” 1998, r. 30, nr 4.

Leszczyńska C., Polska polityka pieniężna i walutowa w latach 1924-1936 w systemie Gold Exchange Standard, Warszawa 2013.

Limanowski Z., Zniszczenia wojenne w budowlach b. Królestwa Polskiego, Warszawa 1918.

Łapa M., Modernizacja państwa. Polska polityka gospodarcza 1926-1929, Łódź 2002.

Łossowski P., Położenie międzynarodowe i polityka zagraniczna, [w:] Polska Odrodzona 1918-1939: państwo - społeczeństwo - kultura, pod red. J. Tomickiego, Warszawa 1982.

Milczarek J., Emigracja zarobkowa z wieluńskiego (1918-1939), „Łódzkie Studia Etnograficzne” 1977, t. 19.

Morawski W., Od marki do złotego. Historia finansów Drugiej Rzeczypospolitej, Warszawa 2008.

Olejnik T., Praszka w latach I wojny światowej, [w:] Nad górna Prosną. Monografia Praszki, pod red. T. Krzemińskiego, Łódź 1999.

Olejnik T., Przeszłość administracyjna Ziemi Wieluńskiej, Wieluń 1996.

Olejnik T., W Polsce odrodzonej (1918-1939), [w:] Nad górna Prosna. Monografia Praszki, pod red. T. Krzemińskiego, Łódź 1999.

Pajewski J., Odbudowa państwa polskiego 1914-1918, Warszawa 1985.

Pankiewicz M., Problem emigracji w Polsce, Warszawa 1935.

Plewko J., Instytucjonalne formy opieki nad emigracja z ziem polskich. Zarys problematyki, „Rocznik Nauk Społecznych" 2009, t. 1(37).

Przeniosło M., Przeniosło M., Rada Główna Opiekuńcza w latach 1918-1921, Kielce 2018.

Spis gmin miejskich $i$ wiejskich Rzeczypospolitej Polskiej, oprac. przez J. Scheinkönig i J. Kowalczewskiego, Warszawa 1934.

Roszkowski W., Rolnictwo i leśnictwo, [w:] Problemy gospodarcze Drugiej Rzeczypospolitej, red. K. Kozłowski, Warszawa 1989.

Ruciński W., Rozwój gospodarczy ziem polskich w zarysie, Warszawa 1963.

Rybczyński K., Charakterystyka społeczno-ekonomiczna ziemi wieluńskiej w okresie międzywojennym, [w:] 30 lat wieluńskiego rolnictwa, Wielun 1974.

Rzepkowski A., Emigracja europejska i pozaeuropejska z województwa łódzkiego w 2. połowie lat 20. XX w. oraz jej skład wyznaniowy i narodowościowy, „Rocznik Łódzki” 2014, t. 61.

Skowron W., Emigracja sezonowa do Niemiec jako zagadnienie społeczne i gospodarcze, Warszawa 1931.

Skowron W., Kryzys i skutki emigracji sezonowej, Warszawa 1932.

Skóra W., Konsulat Rzeczypospolitej Polskiej w Szczecinie w latach 1925-1939. Powstanie i dziatalność, Słupsk 2001.

Skrzypek A., Wobliczu wojny (październik 1938-sierpień 1939), [w:] Historia dyplomacji polskiej, t. 4, pod red. P. Łossowskiego, Warszawa 1995. 
Spaleniak W., Emigracja sezonowa polskich robotników rolnych do Niemiec (1919-1939), Zamość 2010.

Spaleniak W., Prawno-polityczne aspekty emigracji sezonowej polskich robotników rolnych do Niemiec w latach 1919-1939, „Annales Univesitatis Mariae Curie-Skłodowska Lubin - Polonia” 2002, Sectio K, vol. 9.

Szawleski M., Kwestja emigracji w Polsce, Warszawa 1927.

Tomaszewski J., Czynniki wptywające na migracje zewnętrzne ludności w Polsce 1918-1939, [w:] Mechanizmy polskich migracji zarobkowych, pod red. C. Bobińskiej, Warszawa 1976.

Wieś w liczbach w Polsce burżuazyjno-obszarniczej i w Polsce Ludowej, Warszawa 1954.

Wołos M., Szkic o polskiej polityce zagranicznej w międzywojennym dwudziestoleciu, [w:] Dwudziestolecie, pod red. K. Persaka i P. Machcewicza, Warszawa 2009.

Wychodztwo sezonowe do Niemiec, "Robotniczy Przegląd Gospodarczy” marzec 1926, nr 3.

Zacharias M.J., Ku wojnie, [w:] M.K. Kamiński, M.J. Zacharias, Polityka zagraniczna Rzeczypospolitej Polskiej 1918-1939, Warszawa 1998.

Zarychta A., Emigracja polska 1918-1931 i jej znaczenie dla państwa, Warszawa 1933.

Zdziechowski J., Finanse Polski w latach 1924-1925, Warszawa 1925.

Ziemiaństwo - Rolnictwo - Samorządy województwa łódzkiego, t. 1, pod red. Z. Kotkowskiego i S. Grodzieńskiego, Łódź 1928.

\section{Prace niepublikowane}

Michalski M., Powiat wieluński w okresie międzywojennym (1918-1939), Łódź 2017. Rozprawa doktorska napisana w Katedrze Historii Polski Najnowszej Instytutu Historii UŁ pod kierunkiem prof. dr. hab. Kazimierza Badziaka w zbiorach autora.

\section{Michał Michalski}

\section{Emigracja sezonowa do Niemiec z powiatu wieluńskiego w okresie międzywojennym (1918-1939)}

\section{Streszczenie}

Emigracja sezonowa do Niemiec była charakterystycznym zjawiskiem dla powiatu wieluńskiego od 1890 r., skąd corocznie przez cały okres międzywojenny mniejsza lub większa liczba mieszkańców wyjeżdżała (legalnie i nielegalnie) do pracy, kierując się głównie do rolnictwa. Stąd też pochodziła największa grupa w skali powiatowej w Polsce, sięgając rekordowej liczby około 48 tysięcy osób (1926), która wyjechała za Prosnę; przy czym najwięcej chętnych było w 1931 r., gdy taką deklarację złożyło aż 62 tysiące osób. Możliwość wyjazdów do pracy w największym stopniu zależała od polityki niemieckiej, która z wyjątkami (szczególnie wielki kryzys gospodarczy) z chęcią widziała polskich robotników przekraczających granicę w sposób legalny i nielegalny. Także strona niemiecka decydowała o ilości legalnie wyjeżdżających, która zawsze była mniejsza niż liczba chętnych. Ten pęd do pracy u zachodniego sąsiada wynikał z trudnej sytuacji gospodarczej w Polsce, a zwłaszcza w rolnictwie, przekładając się bezpośrednio na rolniczy powiat wieluński. Tym samym emigracja sezonowa była najszybszym i najskuteczniejszym sposobem zatrudnienia bezrobotnych i łagodzenia napięć społecznych na tym terenie.

Słowa kluczowe: II Rzeczypospolita, Niemcy, powiat wieluński, emigracja sezonowa, emigracja zarobkowa 
Michał Michalski

\title{
Seasonal emigration from Wieluń County to Germany during the interwar period (1918-1939)
}

\begin{abstract}
Summary
Seasonal emigration to Germany was a specific phenomenon taking place in Wielun County since 1890. Every year in the interwar period, some inhabitants emigrated for work (legally or otherwise), most pursuing jobs in agriculture. It was also the county responsible for the greatest number of emigrants crossing the Prosna river in Poland. In 1926, 48,000 people temporarily moved to Germany, while the year 1931 saw a record number of seasonal emigrants $-62,000$ people. The possibility of emigrating for work mostly depended on German policies, which with certain exceptions, mainly during the great economic depression - strongly encouraged Polish workers to come there, whether they crossed the border legally or illegally. Germans also specified the number of people legally allowed in, which was always smaller than the actual numbers of those wishing to do so. The willingness to work abroad resulted from the difficult economic situation in Poland, especially in agriculture, withthe rural Wielun County being one the most badly hit. Seasonal emigration was the quickest and the most efficient way of resolving the problem of unemployment and thus alleviating social tensions in the region.
\end{abstract}

Keywords: Second Polish Republic, Germany, Wielun County, seasonal emigration, economic emigration 